\title{
REFORMA AGRARIA Y REVOLUCIÓN LIBERAL EN LOGROÑO DURANTE LA EDAD CONTEMPORÁNEA
}

\author{
Pedro López Rodríguez*
}

\section{La estructura agraria de La Rioja durante la Restauración: ... y punto final}

Los escasos datos que poseemos sobre la titularidad de la tierra y las Memorias, Informes, Libros, etc., escritos durante la Restauración, señalan la enorme fragmentación de las parcelas del suelo riojano, lo que hace que exista un gran número de propietarios con una ínfima propiedad. Lo cual no contradice el hecho de que la concentración de la tierra sea muy alta en algunos municipios de la Rioja, habiendo un número reducido de grandes propietarios latifundistas. Los últimos estudios cuantitativos, casi todos ellos realizados con fuentes fiscales, advierten de esta realidad provincial'. En este punto, aunque apenas adivinamos las profundas transformaciones agrarias que se produjeron en la sociedad rural riojana entre las dos últimas décadas del siglo XIX y la tercera del siglo XX, al menos, distinguimos sus consecuencias más evidentes, y a este respecto, se constata un aumento de la ínfima propiedad, cada vez son más las personas que tributan por una explotación que no es suficiente para la subsistencia familiar.

En el extremo opuesto existe un grupo de grandes propietarios, que en las mismas fechas no hacen sino incrementar sus patrimonios territoriales. Sobre la estructura del latifundio y su evolución, se ha señalado una última etapa de for-

* Doctor en Filosofia y Letras (Historia) y miembro de la Asociación de Historia Contemporánea.

1. BERMEjO MARTíN, Francisco, "La vida político-social (siglos XIX y XX)" en GARCíA PRADO, Justiniano (dir.), Historia de La Rioja, vol. 3, Logroño, 1983, pp. 286-305, del mismo, La Segunda República en Logroño: elecciones y contexto político, Logroño, 1984, pp. 40-52; LÓPEZ RODRÍGUEZ, Pedro, Sociedad riojana y crisis del caciquismo liberal: Logroño 19031923, Logroño, 1991, p. 53-58; del mismo, Calahorra Levítica y Liberal. Cambio socioeconómico y caciquismo liberal en La Rioja Baja 1890-1923, Calahorra, 1997, pp. 18-26. 
mación de grandes propiedades que se sitúa, precisamente, a caballo entre los siglos XIX y XX, cuando "la crisis agropecuaria facilitó, de nuevo, un proceso de concentración de tierras y con él la formación de nuevas y extensas propiedades agrícolas obtenidas por acumulación de pequeños predios; fue ésta labor de una burguesía agraria ya claramente consolidada" ${ }^{\prime 2}$. Así frente al proceso transformación de la propiedad de naturaleza jurídica de la Reforma Agraria Liberal, que posibilitó a comienzos del novecientos la formación de grandes propiedades, la oligarquía agraria, amparada en una situación política como la Restauración que les era totalmente favorable, con una mayor capacidad económica para hacer frente a la depresión finisecular, aprovechó la coyuntura para arrebatar tierras a los pequeños y medianos agricultores, consolidando definitivamente su predominio en el campo español, con la formación por vía acumulativa de latifundios en las primeras décadas del siglo XX.

En el caso de La Rioja, se trata de un grupo numéricamente minoritario, cuyo origen social es diverso, encontrando representantes de la nobleza provincial o la Grandeza de España, terratenientes locales o foráneos. La composición de sus patrimonios puede adoptar asimismo diversas formas: la dispersión de fincas por uno o varios municipios de la provincia o la concentración de la hacienda en un sólo municipio. Si el termino municipal es pequeño, suelen constituirse en el mayor propietario de la localidad, si el municipio es extenso, por lo general, hay un reducido grupo de grandes hacendados, que forman parte de esa elite económica y social local. En general, se combina el absentismo y la opción rentista dentro de esta clase, nombrando un administrador, por lo general perteneciente a ese grupo de medianos propietarios, que administra sus propiedades y recauda las rentas que produce la hacienda. Algunos, llevan directamente sus tierras, aunque se reservan, aquellos cultivos que producen más altos rendimientos como puede ser el viñedo, hortalizas, olivar..., utilizándose en muchos casos el contrato en aparcería.

Pocos son los datos que poseemos del comportamiento de la mediana propiedad, aunque dada la heterogeneidad de este grupo, igualmente debió ser su comportamiento ante la crisis agraria. Desde los que tuvieron que poner en explotación tierras con trabajo asalariado, hasta aquellos que arrendaron parte de sus propiedades, convirtiéndose en rentistas. Los medianos propietarios con menor heredad, tuvieron que poner su ingenio y su capital, para obtener mayores rendimientos, diversificando y modernizando su explotación. Los grupos con mayor desahogo, engrosaron sus haciendas, con la compra de tierras a algunos patrimonios rentistas, que ante la coyuntura de crisis, buscaron mejor acomodo en otros sectores o la pequeña propiedad, que imposibilitada para acometer el pago de los préstamos, tuvo que abandonar sus tierras.

2. ARTOLA, Miguel, BERNAL, Antonio Miguel y CONTRERAS, Javier, El Latifundio. Propiedad y explotación, ss. XVIII-XX, Madrid, 1978, pp. 89-90. 
En buena lógica la crisis agraria finisecular ${ }^{3}$, y en nuestra provincia los efectos de la filoxera, a comienzos del siglo $\mathrm{XX}$, parece debieran haber reducido el número de pequeños propietarios, aunque las fuentes hacendísticas parecen desmentirlo. Se ha comprobado, además, como se reduce la población activa dedicada a la actividad agraria y la fuerte emigración que se produce en la primeras década de la actual centuria. Las claves interpretativas de esta aparente contradicción, deben encontrarse en aquella otra masa de población que no tuvo, ni tan siquiera capacidad de emigrar, que subsiste a base de un mayor nivel de autoexplotación, buscando ingresos complementarios fuera de la hacienda familiar, o bien recurriendo a la demanda de tierra en arrendamiento o a la venta de fuerza de trabajo asalariada. Al hipotético descenso de la pequeña propiedad en los momentos más agudos de la crisis, podría seguir una etapa de recuperación posterior, gracias al desarrollo agrícola y también a la falta de expectativas de empleo en otros sectores productivos, que obligaron a permanecer en el medio rural al pequeño campesinado, aun a costa de reducir su ya precario nivel de vida.

A partir de la segunda década del siglo la dureza de la crisis, vivida con toda su crudeza durante los primeros diez años de 1900, con una situación agrícola insostenible y una creciente conflictividad social campesina ${ }^{4}$, concita el esfuerzo conjunto de la iniciativa publica, fundamentalmente a través de la Diputación Provincial ${ }^{5}$ y de aquellos medianos y grandes propietarios, posibilitados para invertir capital y transformar las estructuras agrarias y productivas tradicionales ${ }^{6}$. El nuevo desarrollo agrario riojano se asienta en una mayor diversidad productiva regional, como ocurre en la Rioja Alta y Media, con la

3. Resulta de obligada referencia para un balance general del impacto de la crisis finisecular en la Europa de fines del siglo XIX los trabajos de GARRABOU, Ramón, "La crisis agraria española de finales del siglo XIX: Una etapa del desarrollo del capitalismo", en GARRABOU, Ramón y SANZ, Jesús (eds.), Historia Agraria de la España Contemporánea. 2. Expansión y Crisis (1850-1900), Barcelona, 1985, pp. 477-542; y GARRABOU, Ramón (ed.), La crisis agraria de fines del siglo XIX, Barcelona, 1988. A nivel regional véase GALLEGO MARTíNEZ, Domingo, La producción agraria de Alava, Navarra y La Rioja desde mediados del siglo XIX a 1935, 2 Tomos, Madrid, 1986.

4. En los primeros años de esta centuria menudean las sociedades de resistencia creadas por jornaleros del campo, fundamentalmente en poblaciones vitivinícolas del partido judicial de Haro. Véase BERMEJO MARTíN, Francisco, 100 años de socialismo en La Rioja. El socialismo en La Rioja (1882-1992), Logroño, 1994, pp. 59-61.

5. Siendo presidente de la Diputación Francisco Martínez González-Zaporta, en diciembre de 1909 se creó la Caja Vitícola Provincial, que tanto contribuyó a la replantación de las vides filoxeradas. Véase BERMEJO MARTíN, Francisco y DELGADO IDARRETA, José Miguel, La Administración Provincial Española. La Diputación provincial de la Rioja, Logroño, 1989, pp. 442-443.

6. La historiografía riojana esta demandando con toda urgencia que se acometa el estudio del movimiento agrario católico y de que manera contribuyó a la mejora de la situación agraria riojana. Los estudios iniciados por Juan Carlos Bilbao Díez hace más de una década no se han continuado y exigen sino por el propio autor, que otro investigador acometa la tarea. 
introducción de productos como la patata o los árboles frutales, en la cuenca del Iregua, que van sustituyendo al monocultivo vitícola; o en la Rioja Baja, con el fomento de una agricultura intensiva, con nuevas plantas, como la remolacha azucarera y las hortalizas, y un ensanchamiento paralelo de la agroindustria ${ }^{7}$. Fue, en definitiva, necesario que la agricultura riojana sufriese la mayor crisis agraria y los más elevados costes sociales de la historia contemporánea, para acometer el proceso de modernización del agro riojano ${ }^{8}$.

\section{Los amillaramientos como fuente para el estudio de la propiedad agraria en los siglos XIX y XX}

La Rioja es una región eminentemente agraria como lo demuestra el hecho de los efectivos agrarios ocupados en la agricultura que en 1887 alcanzan al 70\% de la población activa riojana (1900: 68\%; 1920: 64\%; 1930: 46\%) y como tal cualquier trabajo que pretenda analizar la realidad provincial debe dar principio por reconocer cual es la estructura y distribución de la propiedad de la tierra.

Las dificultades para el historiador en este terreno son, sin embargo, de una magnitud dificilmente superable, pues a diferencia de lo que ocurrió a finales de la Edad Moderna con la confección del Catastro de Ensenada ${ }^{9}$, España va a carecer durante todo el siglo XIX y buena parte del XX, de un Catastro de riqueza rústica; teniéndonos que remitir a los "Amillaramientos" del siglo XIX como fuente primordial para el estudio de la estructura de la propiedad ${ }^{10}$.

7. Para un conocimiento comparado de la evolución económica y la respuesta a la crisis en las diferentes regiones del Valle del Ebro es de gran interés el trabajo firmado por GALLEGO, Domingo, GERMÁN, Luis y PINILLA, Vicente, "Transformaciones económicas en el Valle del Ebro (1800-1936)", en SERRANO SANZ, José $\mathrm{M}^{\mathrm{a}}$ (dir.), Estructura económica del Valle del Ebro, Madrid, 1992, pp. 129-166.

8. Sobre las transformaciones acaecidas en la economía riojana durante los siglos XIX y XX, véase la síntesis general de BERMEJO MARTíN, Francisco, "La economía riojana desde una perspectiva histórica (1850-1980)", en FUENTES QUINTANA, Enrique (dir.), Economía de las Comunidades Autónomas. La Rioja, Revista Papeles de Economía Española, no 12, Madrid, 1993, pp. 59-76.

9. El estudio clásico sobre esta documentación y fundamentalmente sobre la tributación derivada de su confección, conocida como "Unica Contribución", se debe a MATILLA TASCÓN, A., La Unica Contribución y el Catastro de Ensenada, Madrid, 1947. Una de las primeras obras de carácter histórico que utilizó esta fuente y que ha servido de ejemplo para los estudios posteriores es el trabajo de DONÉZAR DÍEZ DE ULZURRUN, J.M., Riqueza y propiedad en la Castilla del Antiguo Régimen. La provincia de Toledo en el siglo XVIII, Madrid, 1984. En nuestra Comunidad destacan los trabajos de ALONSO CASTROVIEJO, Jesús Javier, Logroño 1751. Según las Respuestas Generales del Catastro de Ensenada, Madrid, 1990; y su tesis doctoral, Problemática agraria y solución burguesa. Logroño 1751-1833, Logroño, 1991.

10. SEGURA I MAS, Antoni, "La Reforma de Mon (1845) y los amillaramientos de la segunda mitad del siglo XIX", en SEGURA I MAS, Antoni (cord.), El Catastro en España 1714-1906, vol. I, Barcelona, 1988, pp. 113-114: y nota no 3, p. 131. 
Haciendo una breve reseña histórica sobre la fuente utilizada, hay que señalar que la Ley que introdujo la contribución territorial directa en España fue la reforma tributaria de Alejandro Mon y Ramón Santillán, contenida en la Ley de Presupuestos de 23 de mayo de 1845. Esta normativa sentará las bases del moderno sistema fiscal en España, contribuyendo a la unificación fiscal, añorada por los pensadores ilustrados del siglo XVIII, con la creación de un gravamen sobre el producto líquido resultante de los bienes inmuebles, cultivo y ganadería, que a pesar de todas sus imperfecciones regularizaba los ingresos de un Estado centralizado y uniforme. Este era a todas luces una garantía de progreso, frente al arbitrario sistema del Antiguo Régimen, donde sin ir más lejos la propiedad nobiliaria y eclesiástica gozaban del derecho de exención, lo cual no sucedia con la actual legislación. Por su parte, el Estado se procuraba unos ingresos regulares para atender las necesidades de un estado cada vez más burocratizado.

El nuevo impuesto recaía sobre los rendimientos de los bienes indicados. La Administración del Estado fijaba un cupo recaudatorio global a escala nacional, que se repartía sucesivamente entre las diferentes provincias del reino, y dentro de éstas por municipios, que lo distribuían entre los contribuyentes individualmente, formando en última instancia una documentación que es lo que se conoce como Amillaramiento. En efecto, para llevar a cabo la recaudación del impuesto era necesario evaluar previamente la riqueza imponible a nivel municipal, proceso que se iniciaba con la declaración jurada de los propietarios de los bienes que poseían. Las declaraciones de los propietarios, ordenadas alfabéticamente y especificando minuciosamente las propiedades de cada uno de ellos en clases (regadío, secano, viña, olivares, frutales, etc.) y calidades ( primera, segunda, tercera), junto con el gravamen (líquido imponible) por unidad, clase y calidad de tierra, constituían el Padrón General de Riqueza de cada pueblo o Amillaramiento.

Entre sus principales limitaciones como fuente local de origen fiscal, lo que más destaca es su notable grado de ocultación, especialmente en aquellos lugares en que predomina la gran propiedad, produciéndose una infravaloración no solo en la declaración de la extensión de lo que realmente se posee (ocultación absoluta), sino también en la producción y el rendimiento obtenidos (ocultación relativa), los problemas derivados de la falta de actualización y perpetuidad de los amillaramientos, la utilización de medidas agrarias diferentes según localidades para medir la extensión de las tierras, la variada gama en cuanto a las denominaciones de las calidades de las tierras" ${ }^{11}$. En definitiva, la escasa homogeneidad de criterios a la hora de confeccionar los amillaramientos, hace

11. SEGURA I MAS, Antoni, "Els estudis sobre l'evolució de l'estructura de la propietat de la terra: consideracions generals i qüestions de mètode (s. XVIII-XX)" en III Jornades d"Estudis Histórics Locals. La vida Quotidiana dins la perspectiva històrica, Institut d'Estudis Baleàrics, Palma de Mallorca, 1985, p. 84. Véase también el trabajo de MATA OLMO, Rafael y ROMERO GONZÁLEZ, Juan, "Fuentes para el estudio de la propiedad agraria en España (siglos XVIIIXX). Balance provisional y análisis crítico", Agricultura y Sociedad, no 49, 1988, pp. 231-246. 
que las mismas propiedades y calidades, dependiendo del lugar de residencia, tuviesen un diferente tipo impositivo ${ }^{12}$.

La confección de los Amillaramientos estaba encomendada a una Junta Pericial, compuesta por el mismo número de miembros que los que formaban el Ayuntamiento, que a su vez nombraba a la mitad de los miembros de la Junta Pericial y proponía al Delegado provincial de Hacienda el número de ternas necesario para que éste designase a la otra mitad. El importante papel que ejercía el Ayuntamiento en la constitución de la Junta Pericial y la constante presencia de los medianos y grandes propietarios en los entes locales, significaba en la práctica la existencia de fraudes y agravios comparativos ${ }^{13}$. La ocultación y desigual distribución del importe del impuesto entre los propietarios como señalan Ferrer, Segura y Suau, se relacionan directamente con las estructuras de poder local propias de cada municipio ${ }^{14}$. En definitiva, las posibilidades de fraude, discriminación impositiva y ocultación beneficiaron fundamentalmente a los grandes propietarios, su relación con el nivel político lo confirma Donato Fernández Navarrete cuando dice:

El cacique local gozaba de poderes omnímodos para atraerse los votos populares; para este fin usaba todo tipo de artilugios, entre los que no quedaban excluidos la exención de impuestos, como también el recargo para los contribuyentes disidentes ${ }^{15}$.

Tenidas en cuenta todas estas reservas en cuanto a la utilización de los amiIlaramientos los estudios realizados en los últimos años confirman la alta rentabilidad de esta documentación para el estudio de la estructura agraria nacional ${ }^{16}$. En este sentido, es prácticamente la única fuente seriada con conti-

12. SEGURA I MAS, Antoni, "La Reforma de Mon..." pp. 113-134.

13. Fueron varias las leyes dictadas desde la creación de este sistema tributario para evitar las ocultaciones y los agravios comparativos, la más importante reforma en este sentido fue la Ley de 18 de Junio y Real Decreto de 30 de septiembre de 1885, que señalaba: "serán expuestos los repartos al público, y los propietarios pueden reclamar, primero ante los Ayuntamientos y Comisiones de Evaluación, y en alzada ante la Administración de Hacienda; pudiendo reclamar también las cuotas contributivas, repartiéndose las diferencias que se produzcan, como consecuencia de la resolución, en el reparto del año siguiente". Citado en SEGURA I MAS, Antoni, "La reforma de Mon...", p.130.

14. FERRER, Lloreç, SEGURA I MAS, Antoni y SUAU, Jaume, "Confecció dels "Amillaraments" i poder local: els municipis del Pla de Barcelona, 1851-1874", III Jornades d"Estudis Històrics Locals. La vida Quotidiana dins la perspectiva històrica, Institut d'Estudis Baleàrics, Palma de Mallorca, 1985, pp. 143-148.

15. FERNÁNDEZ NAVARRETE, Donato, "La evolución histórica de la contribución Territorial Rústica", Agricultura y Sociedad, no 8, 1978, p. 186.

16. Un momento importante en cuanto a la clarificación de esta fuente para el estudio de la estructura de la propiedad de la tierra en SEGURA, Antoni, "Fuentes para el análisis de la propiedad de la tierra en el siglo XIX", en /I Curso para historiadores, Instituto Gerónimo de Uztariz, Pamplona, 1987. Utilizo el original mecanografiado y fotocopiado distribuido entre los asistentes a la primera sesión, ya que no hay Actas de este Curso. Los estudios del Grupo de 
nuidad a lo largo del siglo XIX para conocer la distribución de la propiedad y permite el estudio dinámico de la propiedad al poder comparar la evolución de ésta en un mismo municipio, por la confección de varios amillaramientos en un amplio arco cronológico que cubre buena parte de los siglo XIX y XX. Además de poder contrastar esta documentación con otras fuentes como los registros de la propiedad o de hipotecas, protocolos notariales, etc. ${ }^{17}$

\section{El paisaje agrícola de la ciudad de Logroño a finales del siglo XIX}

La fuente que vamos a analizar corresponde al Amillaramiento realizado en Logroño, en el año económico de 1892/1893, incluye todo el término municipal, además de sus dos barrios periurbanos, situados al noroeste y noreste de la ciudad: El Cortijo y Varea. El deficiente estado de conservación de la fuente, que no conserva ni tan siquiera la portada y contraportada del manuscrito, nos ha hurtado alguno de los datos importantes, que sólo el paciente vaciado y reconstrucción de la misma ha permitido conocer ${ }^{18}$.

El término municipal de Logroño tiene una extensión en la actualidad y entonces de 7.744 hectáreas o lo que es lo mismo 40.656 fanegas. Hacemos esta precisión porque vamos a conservar la unidad de medida establecida en la fuente que no es otra que la fanega de 2.722 varas castellanas que equivale a $1.900 \mathrm{~m}^{2}$ o 5,25 fanegas por hectárea. El vaciado de la fuente ha dado como resultado esperado una cantidad de terrazgo inferior a la superficie del término municipal de Logroño, cifrada en las 30.023 fanegas, lo que vendría a significar el $73,84 \%$ de la superficie total ${ }^{19}$. Cifra ésta nada despreciable si tenemos en cuenta que se trata de una fuente fiscal y por lo tanto para nada tiene en

investigación del Instituto Gerònimo de Uztáriz de Pamplona han utilizado los amillaramientos como fuente documental primordial para sus investigaciones, cuyos resultados fundamentales se pueden ver en: "La propiead privada en Navarra a finales del siglo XIX", en GARRABOU, Ramón (coordinador), Propiedad y explotación campesina en la España contemporánea, Madrid, 1992, pp. 93-158 y "Cambio económico y distribución social de la propiedad navarra entre finales del s. XIX y mediados del s. XX", en Boletín del Instituto Gerónimo de Uztariz, no 5, Pamplona, 1991, pp. 57-84. En sentido contrario a la utilización de los amillaramientos pueden consultarse los trabajos de FERRER I ALOS, Llorenç, Pagessos, rabasaires $i$ industrials a la Catalunya Central. Segles XVIII-XIX, Barcelona, 1987, pp. 201-206 y HERNÁNDEZ MARCO, José Luis y ROMERO GONZÁLEZ, Juan, Feudalidad, burguesía y campesinado en la huerta de Valencia, Valencia, 1980, pp. 29-39.

17. SEGURA I MAS, Antoni, "Els estudis sobre...", p. 83-94.

18. La pérdida de las primeras y últimas hojas de la fuente me han impedido conocer lo que se denomina información de carácter general: el total de la extensión de tierras de cada clase y calidad del total de fincas rústicas y urbanas, el total de cabezas de ganado, con distinción de las especies, etc. Sobre la información que suele aparecer en los Amillaramientos véase SEGURA I MAS, Antoni, "La Reforma de..", p. 114.

19. El vaciado del Catastro del Marqués de la Ensenada da un terrazgo de 33.500 fanegas o lo que es lo mismo el $77 \%$ de la superficie total de Logroño. Véase ALONSO CASTROVIEJO, Jesús Javier, Problemática agraria y..., p. 66. 
cuenta aquellas tierras improductivas o no sujetas a algún tipo de gravamen, como pueden ser los cascos urbanos de Logroño, El Cortijo y Varea, el cauce del río Ebro a su paso por la ciudad y su afluente el Iregua, que recorre las fértiles tierras del núcleo de Varea, carreteras, caminos, acequias y cualquier tipo de tierra infructífera por naturaleza.

Hemos agrupado el terrazgo del término municipal de Logroño en ocho grandes grupos: arboleda, cereal, huerta, olivar, viña-olivar, viñedo, pastos-prado y lleco. Después cada uno de ellos se divide en fincas de primera, segunda y tercera calidad, salvo el cereal de regadio, que distingue además entre cereal "cadañero" 20 o de cultivo anual o intensivo, y "año vez" que, como indica su nombre rinde cosecha un año de cada dos. En nuestro análisis vamos a prescindir de las calidades, pues como indica Segura i Mas el fraude provenía en su gran mayoría de la infravaloración de la calidad de las fincas, más que de la reducción superficial del terrazgo ${ }^{21}$.

El reparto de las tierras de Logroño, se ha realizado distinguiendo tan sólo las tierra de regadío y las de secano. Sin tener en cuenta lo que se considera como superficie lleca o improductiva, resulta un total de 29.475 fanegas -véase Cuadro $1-$, de las que 19.948 son clasificadas como de regadío y 9.527 de secano. El regadío ocupaba, pues, el $67,7 \%$ de la superficie de Logroño. De estas 8.581 $\mathrm{fn}$, el $43 \%$ estaban dedicadas al cultivo de cereales y $5.982 \mathrm{fn}$, casi el $30 \%$ lo ocupaban las tierras dedicadas a pastos y prado, el resto se lo repartían el olivar, el viñedo, y la huerta $-2,8 \%$-, sin destacar ninguno de ellos. En cuanto al secano que representaba el $32,3 \%$ de la superficie cultivada de Logroño, el cereal era el producto predominante al ocupar $5.291 \mathrm{fn}$, el 55,5\%, seguido del viñedo con el $17,6 \%$ y 1.673 fn, los pastos llegaban al 13,3\% del secano. Del análisis de los datos, destaca la superficie dedicada al cereal, que ocupa el $47 \%$ de la superficie cultivada de Logroño y la superficie destinada a pastos con el $24,6 \%$. No podía ser de otra forma, si tenemos en cuenta la atención prioritaria de las necesidades alimenticias de la capital. La abundancia de pastos tiene también relación con la producción de carne. El viñedo tan solo ocupa el 10,4\% de la superficie de Logroño, lo que no representa un porcentaje elevado, aquí habría que añadir, sin duda, eso otro $9,3 \%$ de la tierra que aparece bajo la denominación de viña-olivar, otra sembradura que había adquirido auge en estos años, ante los buenos rendimientos que a priori había producido.

La asociación de la vid al cultivo del olivar se ve también con frecuencia y en la generalidad de los casos, en deplorables condiciones. $Y$ no es de extrañar, pues en la mayoría de los casos, la mira primitiva al crearse esta asociación fue la de arrancar la vid cuando el olivo estuviese formado. Después, alhagados (sic) los propietarios por el hecho de que con los productos de una de las

20. Término vulgar que se emplea por "acadañar". Se dice de las tierras óptimas en general. Se siembran todos los años, uno de cereales y otro de patatas o habas.

21. Véase p. 6 y nota $n^{\circ} 11$ en la misma página. 
cosechas costeaban los gastos de la otra, han dejado subsistir los dos cultivos, tocando bien pronto el desengaño de que ninguno de los dos haya podido prosperar. ${ }^{22}$

La huerta, por su parte, solo representaba el 1,9\% del terrazgo logroñés, aunque, sin duda, con altos rendimientos por unidad de superficie.

Cuadro 1. Distribución de la superficie cultivada en la ciudad de Logroño a finales del s. XIX (en fanegas)

\begin{tabular}{|c|c|c|c|c|c|c|}
\hline Cultivo & $\begin{array}{c}\text { Tierra } \\
\text { Regadío }\end{array}$ & $\% *$ & $\begin{array}{l}\text { Tierra } \\
\text { Secano }\end{array}$ & $\% *$ & $\begin{array}{c}\text { Superficie } \\
\text { Total }\end{array}$ & $\% \#$ \\
\hline Arboleda & 50 & 0,2 & & & 50 & 0,2 \\
\hline Cereal & 8.581 & 43,0 & 5.291 & 55,5 & 13.872 & 47,0 \\
\hline Huerta & 565 & 2,8 & & & 565 & 1,9 \\
\hline Olivar & 1.451 & 7,3 & 479 & 5,0 & 1.930 & 6,5 \\
\hline Viña-Olivar & 1.940 & 9,7 & 814 & 8,6 & 2.754 & 9,3 \\
\hline Viñedo & 1.379 & 7 & 1.673 & 17,6 & 3.052 & 10,4 \\
\hline Pastos-Prado & 5.982 & 30,0 & 1.270 & 13,3 & 7.252 & 24,6 \\
\hline \multicolumn{7}{|c|}{$\begin{array}{l}\text { Fuente: A.H.P.L. (Hacienda), Leg. 4222, Amillaramiento Ciudad de Logroño, 1892-93. Elaboración } \\
\text { propia. } \\
\left({ }^{*}\right) \% \text { respecto a la sembradura de regadío o de secano. } \\
(\#) \% \text { respecto a la sembradura total del municipio de Logroño. }\end{array}$} \\
\hline
\end{tabular}

Del análisis de los datos arriba expuestos se comprueba como en el paisaje agrícola de Logroño a finales del siglo XIX domina la sembradura de cereal, frente a la catastrofista visión finisecular de la invasión de viñedo en detrimento del cereal ${ }^{23}$, la imagen que proporcionan los datos empíricos es la normal a una población como la de Logroño a finales del siglo XIX, que demanda productos de primera necesidad, como en este caso son los cereales panificables, elemento básico de la dieta alimenticia, y del que La Rioja era deficitaria hasta el último tramo del siglo ${ }^{24}$. En segundo lugar, se sitúa la superficie dedicada a pastos y prados, con más de siete mil fanegas, lo que supone una cuarta parte de la superficie total, cifra que se nos antoja excesiva, y que mayoritariamente, se encuentra en manos de la gran propiedad, por lo que posiblemente sea otra de las bolsas de fraude más importantes que registra el Amillaramiento de Logroño. En tercer lugar, se encuentra la superficie dedicada al viñedo a la que habría que unir el cultivo denominado viñedo-olivar, que en conjunto

22. DELGADO MASNATA, Antonio Tadeo, Memoria sobre el estado de la agricultura e industrias derivadas en la provincia de Logroño, Logroño, 1876, p. 72.

23. SÁENZ CENZANO, Salvador, en unos apuntes sobre la agricultura riojana finisecular nos recuerda la fiebre de plantar viñas "hasta en los tejados". Véase "Apuntes históricos de Logroño. Agricultura", Berceo, $n^{\circ}$ 5, Logroño, 1947, pp. 523-547 (p. 540).

24. Según la cifras expuestas por GALLEGO MARTÍNEZ, Domingo, La producción agrícola..., p. 201, n. 23: La Rioja pasó de un déficit de trigo de 98.170 Qm., en el período 18911895 a un superavit de 134.678 Qm., en el período 1898-1905. 
viene a representar una quinta parte de la superficie total de Logroño. Es un cultivo, además, en el que predomina el regadío con el $57 \%$ de la tierra dedicada a este producto.

Por lo que respecta al resto de los cultivos y con afán de síntesis, reproducimos las palabras escritas por el médico logroñés Donato Hernández Oñate, cuando se refería, a finales del siglo XIX, a la mayor variedad de cultivos de la capital riojana:

El cultivo en la comarca de Logroño es muy variado, apenas se encuentra una especie útil, que falte en ella; figuran en primer término los cereales, leguminosas, frutas de todas especies, dando buenas cosechas la vid y el olivo, verduras de todas clases y algunos árboles cuyas maderas se aprovechan para la construcción ${ }^{25}$.

En cuanto a la estructura de la propiedad territorial de Logroño en el Amillaramiento de 1892 aparecen 710 propietarios ${ }^{26}$ y un total de 30.023 fanegas cultivables, con lo que a cada propietario le corresponderían 42,28 fanegas $-8 \mathrm{Ha}$. Esta cifra no es sin embargo, más que un simple cálculo matemático que para nada refleja la distribución real de la propiedad de la tierra en el término municipal de Logroño. Para proceder a su análisis he establecido una serie de segmentos de propiedad, que distribuyen la misma de forma que comprende desde el minifundio -menos de una hectárea- hasta la gran propiedad, que hemos situado en las 160 fanegas -30,5 Ha-. Hemos de hacer, sin embargo la precisión de que solamente consideramos en esta clasificación la extensión de cada uno de los propietarios para diferenciarlos, sin tener en cuenta la calidad de la tierra. Atendiendo al estudio efectuado sobre el Catastro del Marqués de la Ensenada ${ }^{27}$ hemos adoptado el mismo modelo, para poder comparar ambas fuentes, a pesar de que situar la gran propiedad a partir de las 30,5 ha nos parece una superficie, excesivamente corta, por lo que vamos a utilizar el término de mayores propietarios, en vez del de grandes propietarios, aunque bajo esta denominación menos concreta encontramos también los grandes terratenientes de Logroño.

$\begin{array}{lc}\text { Segmentos de extensión } & \text { (en fanegas) } \\ \text { Minifundismo } & 0-5 \\ \text { Pequeña propiedad } & 5,1-10 \\ & 11-20 \\ & 21-40 \\ \text { Mediana propiedad } & 41-80 \\ \text { Mayor propiedad } & 81-160\end{array}$

25. HERNÁNDEZ OÑATE, Donato, Topografía médica y..., p. 29.

26. El total de inscripciones que recoge la fuente es de 814 personas distintas de las que 710 son propietarios, 51 aparecen como arrendatarios y 53 contribuyen por alguna utilidad pecuaria (29 por ganadería y 24 por caballería).

27. ALONSO CASTROVIEJO, Jesús Javier, Problemática agraria y..., 1991. 
Cuadro 2. Estructura de la propiedad de la tierra en Logroño,1892-1893

\begin{tabular}{|l|c|c|c|c|}
\hline $\mathrm{N}^{\mathrm{o}}$ fanegas & Propietarios & $\%$ & Tierras $(\mathrm{fn})$ & $\%$ \\
\hline $0-5$ & 223 & 31 & 611 & 2 \\
\hline $5,1-10$ & 137 & 19 & 1.029 & 3 \\
\hline $11-20$ & 112 & 16 & 1.777 & 6 \\
\hline $21-40$ & 87 & 12 & 2.567 & 9 \\
\hline $41-80$ & 76 & 11 & 4.287 & 14 \\
\hline $81-160$ & 49 & 7 & 5.475 & 18 \\
\hline+160 & 26 & 4 & 14.277 & 48 \\
\hline TOTALES & 710 & 100 & 30.023 & 100 \\
\hline
\end{tabular}

Fuente: A.H.P.L. (Hacienda), Leg. 4222, Amillaramiento Ciudad de Logroño, 1892-93. Elaboración propia.

El $78 \%$ de los propietarios - Ios comprendidos entre 0 y 40 fanegas- está por debajo de la media superficial teórica que les correspondería y sólo poseen el $20 \%$ de la tierra -véase Cuadro $2-$. En el otro extremo los medianos y mayores propietarios, esto es, el $22 \%$, controla el $80 \%$ de la superficie agraria de Logroño. Para medir el índice de concentración de la propiedad hay un índice, conocido como Indice Gini (I.G. ${ }^{28}$. El índice conjuga todas las variables utilizadas reduciéndolas a un solo valor que oscila entre 0 y 1 ; a mayor concentración de riqueza el índice se acerca más a 1 , mientras que la menor concentración se da en el valor 0 o concentración perfecta, en la cual la tierra esta distribuida de manera equitativa entre todos los propietarios. El resultado obtenido es del 0,73, cifra realmente elevada, que nos habla de un fuerte control de la tierra en manos de la mediana y gran propiedad $^{29}$. La representación gráfica subsiguiente, no hace sino confirmarnos esta desigual distribución de la propiedad de la tierra en la ciudad de Logroño.

28. Sobre la utilización en los amillaramientos del Indice Gini y su representación gráfica en la curva de Lorenz, véase el trabajo antes citado de SEGURA I MAS, Antoni, "Els estudis sobre...", p. 87. En la misma línea de su argumentación favorable al estudio de los amillaramientos, como fuente para conocer la estructura de la propiedad, manifiesta que "aquestes mesures representen I'unica possibilitat d'aproximar-nos a la comparació d'estructures de propietat diferents" (p. 87).

29. Estudios similares realizados para la provincia de Huesca sobre un Amillaramiento de 1899, indica cifras en todos los casos inferiores: la menor concentración se produce en el distrito de Boltaña con un indice Gini de 0,51, siendo la cifra más elevada la que se da en el distrito de Fraga con un 0,70. En Huesca es del 0,64 y en Jaca del 0,52. Véase FRIAS CORREDOR, Carmen, Liberalismo y republicanismo en el Alto Aragón. Procesos electorales y comportamientos políticos, 1875-1898, Huesca, 1992, p. 183. 
Gráfico 1. Estructura de la propiedad de la ciudad de Logroño, 1892-1893

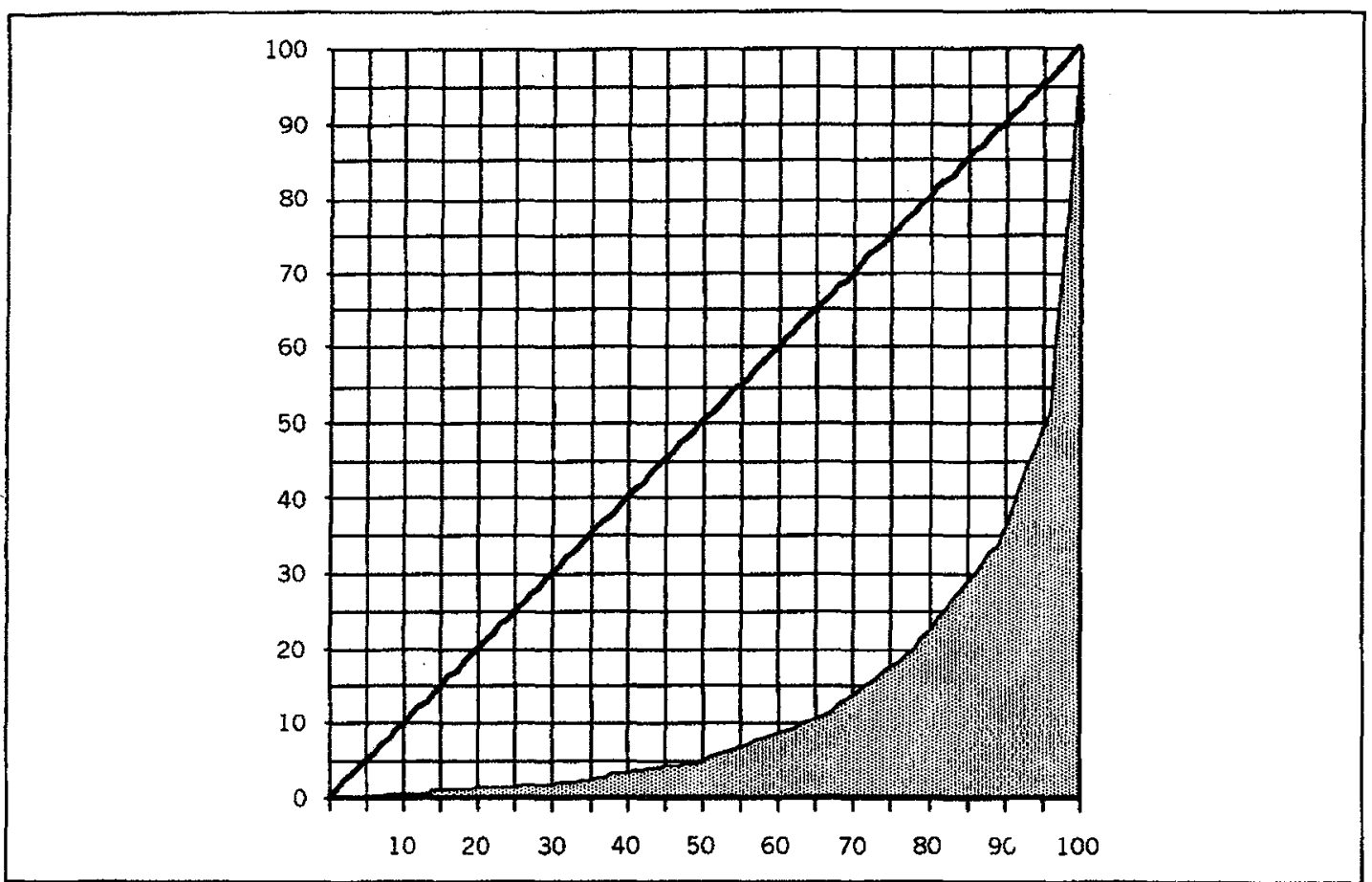

De acuerdo con este gráfico podemos decir que la estructura de la propiedad logroñesa muestra un muy desigual reparto de la riqueza rústica, ya que una minoría de propietarios poseen el mayor número de tierras de la localidad, mientras que la gran mayoría de los labradores logroñeses, viven con unas propiedades que no garantizan la subsistencia familiar, por lo que deben trabajar como arrendatarios, aparceros o jornaleros de los grandes propietarios. Lo cual tiene sus reflejo en una sociedad fuertemente jerarquizada, donde un grupo oligárquico ejerce el control social efectivo, como se manifiesta en la representación del Ayuntamiento de Logroño, donde durante todo el siglo XIX encontramos una destacada presencia de la gran propiedad local ${ }^{30}$.

El análisis de las cantidades y calidades de las tierras de los mayores propietarios, es fundamental para establecer la orientación agraria de la comarca. Al examinar el Cuadro 3 comprobamos, además de la gran cantidad de tierras que poseen, la extraordinaria calidad de las mismas, como indican los porcentajes de cultivos de regadío con índices muy superiores a los cultivos de secano. Por cultivos, vemos como son el cereal y el viñedo los privilegiados por los mayores propietarios. El cereal es en estos momentos de crisis económica un cultivo de más

30. Véase en BERMEJO MARTÍN, Francisco (coord.), Historia de la Ciudad de Logroño. Historia Contemporánea, T. IV y V, Zaragoza, 1994, los epígrafes correspondientes a la representación municipal de los ayuntamientos logroñeses. 
segura colocación en el mercado urbano de Logroño, cuando además La Rioja es deficitaria en su producción ${ }^{31}$. El cultivo de cereal alcanza en los mayores propietarios las 4.729 fanegas, lo que representa el $34 \%$ de la superficie sembrada de cereal en Logroño, por calidades el $37 \%$ está en terreno de regadío y el $29,4 \%$ en secano. El viñedo al que los mayores propietarios dedican las mejores tierras de regadío, representa en esta calidad el $54,1 \%$ de la superficie de viñedo, sin embargo, el viñedo plantado en secano sólo alcanza el 10,5\%; porcentualmente son propietarios de más del 35\% de la tierra dedicada a este aprovechamiento. Su superficie es mucho menor que la sembradura de cereal, pero los grandes propietarios mantienen el control vitivinícola de la comarca. Por su parte, estos tienen además casi un tercio de la huerta y una cuarta parte del olivar de Logroño. Si a ello sumamos el $91,5 \%$ de todos los pastos y prados de la localidad, comprenderemos la capacidad decisoria de estos propietarios en cuanto a la evolución de cultivos y el importante papel que juegan en la comunidad, que recordemos depende todavía prioritariamente de la agricultura.

Cuadro 3. La distribución de cultivos de los mayores propietarios de Logroño 1892-1893 (en fn)

\begin{tabular}{|l|c|c|c|}
\hline \multicolumn{1}{|c|}{ Tipos de cultivo } & Sup. may. prop. & Sup. Logroño & $\% *$ \\
\hline Arboleda & 5 & 50 & 10,00 \\
\hline Cereal Regadío & 3.175 & 8.581 & 37,00 \\
\hline Cereal Secano & 1554 & 5.291 & 29,37 \\
\hline Huerta & 168 & 565 & 29,73 \\
\hline Olivar Regadío & 363 & 1.451 & 25,0 \\
\hline Olivar Secano & 63 & 479 & 13,15 \\
\hline Viñedo Regadío** & 1.795 & 3.319 & 54,08 \\
\hline Viñedo Secano** & 261 & 2.487 & 10,49 \\
\hline Pastos & 6.633 & 7.252 & 91,46 \\
\hline Superficie total & $14.277 \#$ & $30.023 \#$ & $47,55 \%$ \\
\hline
\end{tabular}

Superficie Mayores Propietarios por aprovechamientos totales

\begin{tabular}{|l|c|c|c|c|}
\hline \multicolumn{1}{|c|}{ Tipos de cultivo } & Sup. May. Prop. & $\%$ & Sup. Logroño & $\%^{*}$ \\
\hline ARBOLEDA & 5 & 0,35 & 50 & 10,00 \\
\hline CEREAL & 4729 & 33,12 & 13872 & 34,09 \\
\hline HUERTA & 168 & 1,18 & 565 & 29,73 \\
\hline OLIVAR & 426 & 2,98 & 1930 & 22,06 \\
\hline VINEDOO* & 2056 & 14,40 & 5806 & 35,41 \\
\hline PASTOS & 6633 & 46,46 & 7252 & 91,46 \\
\hline Superficie Total & $14.277 \#$ & $100,00 \%$ & $30.023 \#$ & $47,55 \%$ \\
\hline
\end{tabular}

Fuente: A.H.P.L. (Hacienda), Leg. 4222, Amillaramiento Ciudad de Logroño, 1892-93.

Elaboración propia.

(*) \% en manos de los mayores propietarios respecto a ese cultivo.

$\left({ }^{* *}\right)$ Aparecen conjuntamente la superficie de viñedo y viñedo-olivar.

(\#) La cifra no es el resultado de sumar las cantidades de arriba, sino que expresa la superficie total en cada uno de los conceptos.

31. Véase nota $n^{\circ} 24$, p. 10. 


\section{Agricultura y Propiedad: Balance de la reforma agraria liberal en la Ciudad de Logroño}

La existencia en nuestro marco geográfico de un trabajo sobre el Catastro del Marqués de la Ensenada ${ }^{32}$, me van a permitir hacer balance de los cambios operados en los usos del suelo y la titularidad de la tierra en la ciudad de Logroño. El casi siglo y medio transcurrido entre el Catastro y el Amillaramiento de 1892-93, es un arco cronológico excesivamente dilatado; sin embargo, la ausencia de fuentes que nos aclaren la situación agraria justo después de producirse todo el fenómeno y la certidumbre del dilatado proceso de transformación de la agricultura española durante toda la centuria, nos animan en este empeño de plantear ciertas hipótesis sobre los efectos que la reforma agraria liberal tuvo en nuestra área geográfica ${ }^{33}$.

En este sentido debemos hacer mención en principio a la superficie de regadío y secano -véase Cuadro 4-, mientras en 1751 la superficie de regadío alcanza las 12.815 fanegas, en 1892 esta llega a las 19.948 fanegas, diferencia que se mantiene en términos relativos, pues si en la primera fecha corresponde al $54,6 \%$ del la superficie total en la última representaría el $67,7 \%$. Por lo que respecta al secano son 10.648 fanegas frente a 9.527 de 1892 , o lo que es lo mismo el $45,4 \%$ en 1751 frente al 32,3\% de finales del siglo XIX. En términos globales la superficie cultivable de Logroño ha experimentado un crecimiento de 6.012 fanegas, lo cual supone un $25 \%$ más de tierra útil para el cultivo. Ello representa un incremento considerable de la superficie regable, con más de seis mil fanegas, normal si tenemos en cuenta el siglo y medio transcurrido entre una fecha y otra, y el desarrollo tecnológico consiguiente, lo que permitió una extensión del regadío ${ }^{34}$, mientras el secano retrocede, reduciéndose su extensión entre una y otra fecha en 1.121 fanegas.

En cuanto al cereal observamos como las cifras se mantienen, incluso la sembradura ha descendido un poco (200 fanegas) con respecto al Catastro. Con lo

32. ALONSO CASTROVIEJO, Jesús Javier, Problemática agraria..., 1991.

33. Los trabajos a nivel provincial sobre las transformaciones agrarias del siglo XIX se han dirigido fundamentalmente al tema de la desamortización, destacan los trabajos de LÁZARO TORRES, Rosa Má, La desamortización de Espartero en Logroño, Logroño, 1977; BILBAO DIEZ, Juan Carlos, La desamortización de Pascual Madoz en la ciudad de Logroño y su partido judicial (1855-1856), Logroño, 1983. Los primeros trabajos de renovación que comienzan a tratar el tema de la propiedad de la tierra de forma integral corresponden a BAICORRI, Artemio J., "La estructura básica de la agricultura riojana", en GAVIRIA, Mario y BAIGORRI, Artemio J. (eds), El Campo Riojano, Zaragoza, Tomo l, 1984, pp. 131-166; ALONSO CASTROVIEJO, Jesús Javier, Problemática Agraria y solución burguesa. Logroño, 1750-1833, Logroño, 1991 y LOPEZ RODRIGUEZ, Pedro, Elites y Poder. Cambio estructural y dinámica política bajo el caciquismo liberal, La Rioja, 1890-1923, Logroño, 1997, tesis doctoral inédita.

34. En el verano de 1880 se inaugura el "Pantano de la Grajera", iniciativa de un grupo de grandes propietarios de Logroño, que pretenden un mejor aprovechamiento de las aguas de los ríos Somero y Bajero. Obra a cargo del Ayuntamiento será iniciada por el ingeniero Cesáreo Moroy y terminada por Amós Salvador y Rodrigáñez. 
que el término de Logroño con tres veces más población que en $1751^{35}$, debía ser deficitario, a pesar de que la productividad lógicamente habría mejorado al incrementarse la superficie de cereal de regadío en la misma proporción que disminuía el cereal en secano. Ahora ya no ocurría como en 1751 que se reservaban las mejores tierras para el viñedo, cuya producción era mayor en regadío y sus beneficios superaban a los producidos por el cereal ${ }^{36}$. Las mejores tierras se van a destinar para el cultivo de cereal que proporciona unos ingresos más seguros y no necesita de un trabajo tan continuado y especializado.

Cuadro 4. Distribución de la tierra cultivada de Logroño en 1751 y 1892 (en fn)

\begin{tabular}{|c|c|c|c|c|c|}
\hline Calidad de la tierra & 1751 & $\% *$ & 1892 & $\% *$ & Dif. 1892-1751 \\
\hline Superficie de regadío & 12.815 & 54,62 & 19.948 & 67,68 & 7.133 \\
\hline Superficie de secano & 10.648 & 45,38 & 9.527 & 32,32 & -1.121 \\
\hline Superficie total & 23.463 & 100,00 & 29.475 & 100,00 & 6.012 \\
\hline \multicolumn{6}{|c|}{ Distribución por aprovechamiento (regadío y secano) } \\
\hline Tipo de cultivo & 1751 & $\% *$ & 1892 & $\% *$ & Dif. 1892-1751 \\
\hline Arboleda & & 0,00 & 50 & 0,17 & 50 \\
\hline Cereal Regadío & 7.540 & 32,14 & 8.581 & 29,11 & 1.041 \\
\hline Cereal Secano & 6.532 & 27,84 & 5.291 & 17,95 & -1.241 \\
\hline Huerta & 407 & 1,73 & 565 & 1,92 & 158 \\
\hline Olivar Regadío & & 0,00 & 1.451 & 4,92 & 1.451 \\
\hline Olivar Secano & & 0,00 & 479 & 1,63 & 479 \\
\hline Viñedo Regadío & 4.868 & 20,75 & $3.319+$ & 11,26 & -1.549 \\
\hline Viñedo Secano & 2.147 & 9,15 & $2.487+$ & 8,44 & 340 \\
\hline Pastos y Prados & $1.969 \#$ & 8,39 & 7.252 & 24,61 & 5.283 \\
\hline Superficie total & 23.463 & 100,00 & 29.475 & 100,00 & 6.012 \\
\hline \multicolumn{6}{|c|}{ Distribución total por aprovechamiento } \\
\hline Tipo de cultivo & 1751 & $\% *$ & 1892 & \%* & Dif. $1892-1751$ \\
\hline ARBOLEDA & & 0,00 & 50 & 0,17 & 50 \\
\hline CEREAL & 14.072 & 59,98 & 13.872 & 47,06 & -200 \\
\hline HUERTA & 407 & 1,73 & 565 & 1,92 & 158 \\
\hline OLIVAR & & 0,00 & 1.930 & 6,55 & 1.930 \\
\hline VINEEDO & 7.015 & 29,90 & $5.806+$ & 19,70 & -1.209 \\
\hline PASTOS Y PRADOS & $1.969 \#$ & 8,39 & 7.252 & 24,61 & 5.282 \\
\hline Superficie total & 23.463 & 100,00 & 29.475 & 100,00 & 6.012 \\
\hline \multicolumn{6}{|c|}{$\begin{array}{l}\text { Fuentes: ALONSO CASTROVIEJO, Jesús Javier, Problemática agraria y solución burguesa. Logroño, } \\
\text { 1750-1833, Logroño, 1991, pp. } 68 \text { y 75; y A.H.P.L. (Hacienda), Leg. 4222, Amillaramiento de la Ciudad } \\
\text { de Logroño, I892-93. Elaboración propia. } \\
\text { (*) \% respecto a la superficie cultivada de Logroño en esa fecha. } \\
\text { (+) Aparecen conjuntamente la superficie de viñedo y viñedo-olivar. } \\
\text { (\#) Corresponde a la superficie ocupada por las Dehesas del Común, terrenos utilizados para que } \\
\text { pastaran los ganados de los vecinos de Logroño. }\end{array}$} \\
\hline
\end{tabular}

35. Según el Catastro del Marqués de la Ensenada Logroño tenía en 1751 una población de 6.136 habitantes. El Censo de Población de Logroño de 1887 da una población de 15.567 personas.

36. ALONSO CASTROVIEjO, Jesús Javier, Problemática agraria..., p. 70. 
Por lo que respecta al viñedo vemos como la superficie se ha reducido de manera importante, afectando exclusivamente al regadío, con una reducción de 1.549 fanegas, ello favoreció el incremento de la superficie de cereal, pero también el olivar, que necesita un menor trabajo y que aparece como variedad de cultivo, para atender la demanda oleaginosa de la ciudad ${ }^{37}$. Al olivar se destinan también las tierras de mejor calidad, ocupa tres veces más terrenos de regadío que de secano, con 1.451 fanegas frente a las 479 de olivar de secano. Lo cual es una evidencia más de como la actividad agraria pierde importancia dentro de los sectores productivos de la ciudad. La elevada superficie dedicada a pastizales y prados, que pasa de las 1.969 fn que ocupaban las Dehesas del Común ${ }^{38}$, según el Catastro del Marqués de la Ensenada, a las $7.252 \mathrm{fn}$ de pastizales que declara el Amillaramiento de 1892, confirman esta pérdida de peso específico de la actividad agraria y son manifestación, además, de la situación de crisis que vive la agricultura riojana y española, dentro del fenómeno de la crisis "agrícola y pecuaria" finisecular. La demostración más palmaria de esta situación es que son los grandes propietarios los que poseen más del $90 \%$ de esta superficie ante la falta de una clara orientación agrícola.

Si comparamos, ahora, los resultados del Catastro del Marqués de la Ensenada en cuanto a la superficie en manos de los mayores propietarios sucede que en 1751 los 19 mayores propietarios de Logroño, controlaban 5.735 fanegas, esto es el $26,7 \%$ de la tierra, mientras en 1892, son 26 propietarios los que tienen 14.277 fanegas, esto es el $47,5 \%$ de la propiedad rústica. Con una menor concentración de la tierra en la primera de las fechas, se mantienen prácticamente las superficies y porcentajes de cada una de los productos de sembradura -véase Cuadro 5-, con la única excepción del viñedo de regadío, que refleja una mayor concentración de la propiedad en manos de los mayores propietarios en 1892. Lo cual confirma las escasas transformaciones que la gran propiedad introduce en los usos del suelo, una vez los efectos de la Reforma Agraria Liberal son ya perceptibles a estas alturas de la centuria. A pesar de los cambios, que como luego veremos, se producen en cuanto a la composición social de los propietarios, que es donde parece ser se concentran todos los esfuerzos de la burguesía española del XIX, a la búsqueda de la mutación en la titularidad de la tierra. La nueva orientación, si acaso, se observa en el viñedo, que no aumenta su superficie en términos globales, pero que se concentra en menos manos. De las 7.015 fanegas de viñedo existentes en 1751 los mayores

37. A.H.P.L. (Catastro del Marqués de la Ensenada), Leg. 333, fol. 24. En Logroño en la época del Catastro del Marqués de la Ensenada el olivar es un cultivo residual, como informan las Respuesta Generales, aparece algun plantio de olivos "en las heredades de tierra y viñas".

38. Entre 1809 y 1813 se procedió a la venta de bienes del Común. La totalidad de la tierra correspondía a la Dehesa de Varea. Como resultado de estas ventas el Ayuntamiento se quedó sin ningún tipo de bien comunal. Fueron las clases desposeídas de la ciudad de Logroño las que más sufrieron con esta enajenación. Véase ALONSO CASTROVIEJO, Jesús Javier, Problemática agraria $y . . .$, p. 147. 
propietarios controlaban el $14,7 \%$ de la superficie, mientras que en 1892 poseen el $35,4 \%$ de las escasas 5.806 fanegas $^{39}$. Proceso este que se demuestra como natural de acuerdo con las perspectivas de un mercado capitalista en el que el viñedo es un producto de alta rentabilidad económica ${ }^{40}$, teniendo en cuenta además las importantes perspectivas a la exportación de nuestros caldos, que se abrieron para este producto a partir de la década de 1870-1880 con motivo de la extensión de la plaga de la filoxera en Francia y el tratado comercial firmado con el vecino país en 1882, que renovaba por diez años el tratado de 1877, rebajando aún más los aranceles de los productos franceses ${ }^{41}$. Coyuntura favorable que se redujo drásticamente tras la renuncia del mismo en 1891 y todavía más a comienzos de siglo con la invasión de la filoxera en los viñedos riojanos ${ }^{42}$.

Cuadro 5. Distribución comparada de cultivos de los mayores propietarios de Logroño, 1751-1892 (en fn)

\begin{tabular}{|c|c|c|c|c|}
\hline Cultivos & Superficie 1751 & $\% *$ & Superficie 1892 & $\% *$ \\
\hline Cereal regadio & 2.886 & 38,3 & 3.175 & 37,0 \\
\hline Cereal secano & 1.691 & 25,9 & 1.554 & 29,4 \\
\hline Huerta & 128 & 31,5 & 168 & 29,7 \\
\hline Olivar regadio & -- & -. & 364 & 25,1 \\
\hline Olivar secano & -- & -- & 63 & 13,1 \\
\hline Viñedo regadío & 763 & 15,7 & $1.795 * *$ & 54,1 \\
\hline Viñedo secano & 266 & 12,4 & $261 * *$ & 10,5 \\
\hline Pastos & -- & & 6.633 & 91,5 \\
\hline Totales & 5.735 & 100,0 & 14.277 & 100,0 \\
\hline \multicolumn{5}{|c|}{$\begin{array}{l}\text { Fuentes: ALONSO CASTROVIEJO, Jesús Javier, Problemática agraria y solución } \\
\text { burguesa. Logroño, } 1750-1833 \text {, Logroño, 1991, Cuadro 11, p. } 79 \text { y A.H.P.L. (Hacienda), } \\
\text { Leg. } 4222, \text { Amillaramiento de la Ciudad de Logroño, 1892-1893. Elaboración propia. } \\
\left({ }^{*}\right) \% \text { respecto a la superficie cultivada de esa especie en la fecha citada. } \\
(* *) \text { Aparecen conjuntamente la superficie de viñedo y viñedo-olivar. }\end{array}$} \\
\hline
\end{tabular}

39. En esta última cifra se ha sumado como viñedo el grupo viñedo-olivar. Si no contabilizamos conjuntamente ambos aprovechamientos, y solamente nos referimos al viñedo el porcentaje resultante supera el $40 \%$, lo que supone un porcentaje aún más elevado en manos de los mayores propietarios. Por lo que respecta al total del plantio viñedo-olivar controlaban más del el $30 \%$ de la superficie.

40. Recientemente ha aparecido un artículo firmado por IBÁÑEZ RODRÍGUEZ, Santiago y ALONSO CASTROVIEJO, Jesús Javier, "Especialización agraria en el Alto Ebro (La Rioja): La cultura del vino, 1500-1900", Brocar, no 20, 1996, pp. 211-235. Análisis de larga duración sobre un producto como el vino que los autores consideran de "marcado carácter comercial y generador de riqueza monetaria" (p. 215).

41. Para los efectos de los tratados comerciales sobre el sector vitivinícola español véase PAN-MONTOJO GONZÁLEZ, Juan Luis, "El vino y la política comercial en la Restauración", en Agricultura y Sociedad, no 72, Madrid, 1994, pp. 167-204.

42. GALLEGO MARTÍNEZ, Domingo, La producción agraria..., p. ?. Sobre la evolución vitivinícola nacional a partir de estos años véase el trabajo de PAN-MONTOJO, Juan, La bodega del mundo. La vid y el vino en España (1800-1936), Madrid, 1994, pp. 252 y ss. 
El Catastro del Marqués de la Ensenada ${ }^{43}$, a pesar de los 141 años transcurridos desde su elaboración, refleja una situación muy similar a la descrita anteriormente, las transformaciones experimentadas tras el paso de la reforma agraria liberal no parecen haber alterado significativamente la estructura de la propiedad. Si acaso el cambio más notable es la secularización de la propiedad de la tierra, pues si en el Catastro los primeros puestos pertenecen al Clero, la propiedad de la Iglesia es en estos momentos mínima ${ }^{44}$, las sucesivas desamortizaciones del siglo XIX han transmitido la titularidad de la tierra a los seglares -véase Cuadro 6-. De ahí el importante cambio en la nómina de los grandes propietarios desde 1751, cambio que ya es apreciable y perfectamente visible en 1818 cuando se realiza el Apeo de Garay, donde ya distinguimos algunos de los mayores propietarios que vemos en el Amillaramiento de $1892^{45}$-véase Cuadro 7-. Otro aspecto destacado y que diferencia una y otra fecha es la mayor concentración de la propiedad, producto también, sin duda, del proceso desamortizador, reflejado en el índice Gini de Logroño que es en 1751 del 0,62 y en 1892 llega al 0,73. Concentración evidente con sólo comparar la superficie de los mayores propietarios, pues si en el Catastro el mayor propietario, el Cabildo de la Redonda posee una superficie total de 608 fanegas, en 1892, un solo propietario, José María Lasuen, es propietario de 2.240 fanegas -véase Cuadro 7-.

Cuadro 6. Evolución de la titularidad de la tierra de los mayores propietarios en la ciudad de Logroño (en fanegas)

\begin{tabular}{|l|c|c|c|c|c|c|}
\hline Tipo de propiedad & Año 1751 & $\%$ & Año 1818 & $\%$ & Año 1892 & $\%$ \\
\hline Propiedad Eclesiástica & 3.385 & 59,0 & 2.697 & 28,6 & 0 & 0,0 \\
\hline Propiedad Seglar & 2.350 & 41,0 & 6.726 & 71,4 & 14.277 & 100,0 \\
\hline Total Superficie & 5.735 & 100,0 & 9.423 & 100,0 & 14.277 & 100,0 \\
\hline
\end{tabular}

Fuentes: ALONSO CASTROVIEJO, Jesús Javier , Problemática agraria y solución burguesa. Logroño, 1750-1833, Logroño, 1991, pp. 79 y 96; y A.H.P.L. (Hacienda), Leg. 4222, Amillaramiento de la Ciudad de Logroño, 1892-1893. Elaboración propia.

En conclusión, de 1751 a 1892, casi siglo y medio separan ambas fechas y en este lapso de tiempo tuvo lugar un proceso revolucionario, que transformó la estructura agraria de España, no sólo en cuanto a los usos del suelo, sino,

43. ALONSO CASTROVIEJO, Jesús Javier, Problemática agraria..., pp. 76 y ss. Se realiza también en esta obra el análisis del Apeo de Garay de 1818, que proporciona resultados todavía más parejos con los del amillaramiento de 1892-93, aunque la mayor fiabilidad del Catastro hace que nos centremos en él.

44. En el amillaramiento de 1892 el Cabildo de la Redonda tiene amillarada tan sólo una finca de cereal de regadío de 10 fanegas de extensión. Aparecen, además, inscritas tres Capellanías, con una extensión total de 73 fanegas, lo que unido a las propiedades de la Colegiata de la Redonda hace un tal de 83 fanegas, un 0,3\% de las superficie de Logroño. Esto es ya solo lo que se mantiene en manos de la Iglesia, de forma directa.

45. ALONSO CASTROVIEJO, Jesús Javier, Problemática agraria..., pp. 79 y 96. 
sobre todo, el régimen de tenencia, ahora de carácter burgués, desapareciendo con ello los viejos usos y costumbres del Antiguo. Régimen y la multiplicidad de dominios, cargas y tributos que gravaban la propiedad feudal. Pero fue, sin duda, la composición social de los propietarios de tierra, la que evidenció una más profunda transformación, y fue en el caso concreto de Logroño la propiedad amortizada en manos del Clero, la que se disolvió de manera más elocuente, quizás por su más que destacada presencia en la ciudad de Logroño a finales del Antiguo Régimen ${ }^{46}$. Un nuevo grupo social de origen burgués, pero engalanado en muchos de los casos con el bruñido de un título nobiliario, se haran con la mayoría de estas propiedades gracias a los diferentes procesos desamortizadores del siglo XIX, que les permitirá aparecer en los primeros puestos en las listas comtributivas de la ciudad. Finalmente ocuparán los puestos de representación política local y regional, siempre en la defensa de la Corona y el orden, emblema de la burguesía que marcará todo el siglo XIX. Pero quizás, de manera más extrema en el caso riojano, por la proximidad del escenario bélico, en la lucha fraticida con las provincias vascongadas y el carlismo, y por la coincidencia con sus intereses particulares, que requerían la apariencia de normalidad y progreso para completar los patrimonios privados de la nueva sociedad burguesa. El resultado, el ya descrito, una sociedad de propietarios cuyos patrimonios insultaban la desoladora condición de un campesinado, enfrentado a la férrea ley del mercado capitalista, que no garantizaba la mínima cobertura social.

El proceso revolucionario liberal burgués del siglo XIX liquidó los vestigios del régimen feudal, acabando no sólo con la propiedad amortizada en manos de la Iglesia, sino también con aquellas propiedades que había constituido la base fundamental de la "economía popular" y que había supuesto desde siglos la fuente de superviviencia de muchas familias, como indica muy acertadamente Pedro Ruiz Torres en un reciente balance:

La revolución burguesa liquidó los restos del feudalismo y terminó con la cada vez más difícil supervivencia de esa "economía popular", pero también eliminó el monopolio de la propiedad eclesiástica y de la propiedad municipal. El resultado de la revolución fue de nuevo la concentración de la tierra en manos de un reducido grupo de propietarios, aunque ahora de distinto perfil social y abierto a la renovación como no lo había estado antes, no en vano las nuevas "clases propietarias" carecían de los privilegios que habían inmovilizado y acrecentado el antiguo monopolio de la tierra ${ }^{47}$.

46. Véase ALONSO CASTROVIEJO, Jesús Javier: Logroño 1751. Según las Respuestas Generales del Catastro de Ensenada, Madrid, 1990, pp. 32-34.

47. RUIZ TORRES, Pedro, "Reforma agraria y revolución liberal en España", en GARCíA SANZ, Angel y SANZ FERNANDEZ, Jesús, Coords., Reformas y políticas agrarias en la historia de España (De la llustración al primer franquismo), Madrid, 1996, pp. 228-229. Este trabajo recoge las últimas novedades que se han producido en la reciente producción historiográfica sobre la reforma agraria liberal. En este sentido merece destacarse los trabajos incluidos en SAAVE- 


\section{Propiedad territorial y representación política: los mayores propietarios de Logroño}

El nomenclátor al que nos vamos a referir refleja una parte mínima de la nómina que representa la gran propiedad de la provincia ${ }^{48}$, soy consciente de las limitaciones de la fuente que tan sólo se refiere al término municipal de Logroño, pero también es expresión de una parte importante de esta misma propiedad como lo confirma el hecho de que la mayoría de los grandes propietarios de Logroño aparece en los primeros puestos de las listas provinciales, que periódicamente se publica en el Boletín Oficial de la Provincia. El seguimiento de la propiedad pone de relieve, la estrecha relación que existe entre la gran propiedad y la máxima representación política provincial. Así, se comprende plenamente la afirmación de que "el régimen local de la Restauración significó el ruralismo del Estado o el triunfo de la provincia; la capitulación del Estado frente a una parte sectorial de la sociedad ${ }^{\prime 49}$. La abrumadora representación en el cuerpo electoral riojano de los propietarios agrícolas, resalta su peso en las decisiones políticas y revela la importancia del "cacique" en un mundo mayoritariamente rural como el riojano y el español.

El grupo de los mayores propietarios en el Amillaramiento de 1892 son 26 personas e instituciones que poseen 14.277 fanegas, el $48 \%$ de la superficie cultivable de Logroño. Estas cifras evidencian la importancia de unos pocos propietarios y el peso relevante que ejercen en la comunidad ${ }^{50}$. Los más destacados son personajes de sobra conocidos en Logroño como José Rodríguez Paterna Gilberte, Lucas Rodrigáñez Mateo Sagasta, Juan Domingo Santa Cruz García, los marqueses del Romeral, Murrieta, la Habana, San Nicolás, Orovio ${ }^{51}$,

DRA, Pegerto y VILLARES, Ramón (eds.), Señores y campesinos en la Península Ibérica, siglos XVIII-XIX, 2 tomos, Barcelona, 1991 y el escelente trabajo de ROMERO HERNÁNDEZ, Ricardo, Economistas y reformadores españoles: La Cuestión Agraria (1760-1935), Madrid, 1993.

48. En la obra de BERMEJO MARTÍN, Francisco y DELGADO IDARRETA, José Miguel, La Diputación provincial..., pp. 56-57, pp. 130-133 y pp. 344-345; podemos ver la nómina de los principales propietarios de la provincia desde la tercera década del siglo XIX. No es más que como dicen los autores, un primer paso para el estudio de la propiedad de la tierra y además realizado sobre cuotas contributivas y no en base a la propiedad territorial, pero muy importante, porque podemos establecer un seguimiento de los principales propietarios de La Rioja, durante los siglos XIX y XX.

49. GALLEGO ANABITARTE, Alfredo, "Notas histórico-jurídicas sobre el Régimen Local Español", en Revista de Estudios de la vida local, 1970, p. 273.

50. Los datos que proporcionamos de la mayoría de los propietarios tienen procedencia muy diversa. Identificar la referencia exacta de las fuentes sería muchas veces más prolijo que los datos proporcionados, de ahí que a veces no hagamos mención de las mismas.

51. Junto a la hija de Manuel Orovio, Isabel Orovio y Fernández Urrutia y el hijo de ésta, Manuel Eulate y Orovio, vecinos de Alfaro, podríamos situar a los Fernández Urrutia con quien residen, ya que el patrimonio de su tío Vicente Fernández Urrutia y Benito del Valle $(+24$ abril 1881), que alcanza las 467 fanegas de tierra, acaba de ser repartido entre sus hijos. Juntando el patrimonio de todos ellos se colocarían en los primeros puestos de los mayores contribuyentes de Logroño. 
Felipe de la Mata Fernández, Casimiro Miguel y Soret, Fermín de Castejón y Gómez de la Serna. La mayoría de estos últimos alcanza la más alta representación política provincial, podemos ver alcaldes, senadores, diputados, e incluso ministros y presidente de gobierno entre sus miembros. Pero a la cabeza de los mayores propietarios se encuentra José María Lasuen quien contribuye como forastero ${ }^{52}$ y tiene sus propiedades en el término de la Rad (Varea), en su mayoría son tierras de secano con pastos, por lo que su importancia es mucho menor de lo que sus 2.240 fanegas hacen pensar -véase Cuadro 8-. Otros propietarios que aparecen en esta lista son el abastecedor de carnes Eusebio Iradier Arandia, la vecina de Agoncillo Melitona Ayarza, Francisco Aguilera Segura, el varias veces diputado provincial Martín Navasa Ezquerro $^{53}$, Eusebio Nalda Torres, Antonio Valdemoros Melón y Félix Bargo Sierra, estos tres últimos vecinos de El Cortijo y con tierras de ínfima calidad. Otros individuos de esta lista como el vecino de Madrid, Pedro $\mathrm{M}^{\mathrm{a}}$ Montoya ${ }^{54}$, sin duda relacionado con el diputado provincial y destacado propietario territorial Juan Bautista Montoya Blázquez; Mónica Moreno es la mujer del coronel del Ejército Martín Alesanco Cadalso; Paz Almorín Santa Cruz, casada con Justo Zugarramurdi Velasco, que a finales de 1900 a la muerte de su mujer recibe en herencia todas sus propiedades; Leocadia Espinosa Urrutia, casada con el propietario Sebastián Gimeno Martínez, que contribuye en 1880 con 413 pesetas por territorial; igual que María del Barrio Alvarez, vecina de Madrid, de la que apenas tenemos datos ${ }^{55}$. Más conocida es la Marquesa de la Lapilla, quien aparece en las listas de los mayores contribuyentes

52. En la lista de personas que prestaron dinero para el tanteo y consumo de las regidurías perpetuas de la ciudad de Logroño en el año 1801 aparece un tal José María Lasuen (comerciante-hacendado) quien contribuye con la máxima cantidad. Hasta la muerte de Fernando VII, encontramos a esta familia tomando parte activa en los asuntos de la ciudad, después le perdemos la pista. Véase ALONSO CASTROVIEJO, Jesús Javier, Problemática agraria y... pp. 205-224.

53. Diputado provincial por el distrito de Calahorra-Alfaro en cinco ocasiones por el partido conservador: 1890, 1893, 1898, 1903 y 1907 y vicepresidente de la Diputación en 1894. Véase BERMEJO MARTÍN, Francisco y DELGADO IDARRETA, José Miguel, La Diputación provincial..., pp. 406 y 431. Esta es la obra de referencia siempre que hablemos de Diputación provincial de la Rioja. Martín Navasa Ezquerro era cuñado del industrial republicano Salustiano Marrodán López.

54. A.H.P.L. (Hacienda), Leg. 4.108, Declaración de propietarios de rústica de la capital: María Montoya Alcalde, 1901 y Leg. 4.068, Apéndice de Amillaramiento. Sus propiedades las recibirá en herencia su hija María Montoya, casada con Ricardo Fernández Heredia. En 1926 se realiza en Madrid la partición de sus bienes, que pasarán a manos del hijo de estos Juan José Fernández Montoya, vecino de Madrid.

55. Tenemos noticias de un tal Luis Gonzaga del Barrio, religioso cartujo nacido en Logroño en 1776 y fallecido en la Cartuja de Miraflores (Burgos) en 1848, hijo primogénito de una distinguida familia logroñesa, que heredó un cuantioso mayorazgo (1799), renunciando a favor de un hermano suyo. Véase GONZÁLEZ GONZÁLEZ, Pedro Pbro., Biografia de Riojanos Ilustres, original manuscrito, Logroño, $\mathrm{s} / \mathrm{f}$. 
estatales de 1875, con propiedades en las provincias de Badajoz, Barcelona, Sevilla y Soria ${ }^{56}$.

El máximo representante provincial en este sentido es Juan Domingo Santa Cruz García emparentada consanguíneamente con Espartero ${ }^{57}$, sus apellidos están ligados a los mayores propietarios de la provincia desde los inicios del ochocientos, con una hacienda que no hizo sino incrementarse hasta los umbrales del presente siglo, y que vemos intervenir en todos los procesos desamortizadores desde el reinado de Carlos IV ${ }^{58}$. La relevancia de esta familia, reconocida desde hace poco tiempo, ha hecho crecer el interés por el estudio del origen de esta gran fortuna familiar ${ }^{59}$. El fundador de esta casa, el logroñés Domingo Santa Cruz Velasco, comerciante en Cartagena de Indias (Colombia), donde establece una importante red comercial, se asienta en Logroño definitivamente en 1782 y desde aquí gestiona su Casa de Comercio, extendiendo su red comercial por las principales ciudades castellanas. Su vinculación con la política, desde las filas de un liberalismo exaltado, busca lo que muchos afrancesados y liberales deseaban en estos años iniciales del siglo XIX, el arrumbamiento del Antiguo Régimen y la instauración del Régimen Liberal, para un más próspero desarrollo de sus negocios, encorsetados por un rígido funcionamiento de la economía borbónica. El destino vinculó a esta familia con Baldomero Espartero, símbolo del progresismo, y desde entonces poder económico y representación política, siempre estuvieron unidos en la Casa de los Santa Cruz.

Domingo Santa Cruz Velasco casado con Inés Orive Torrano, tuvo tres hijos que llegaron a la edad adulta y cambiaron de estado civil: Francisco Javier, José y Anacleta Santa Cruz Orive. Esta última contrajo matrimonio con Ezequiel Martínez de Sicilia, la hija de estos, Jacinta Martínez de Sicilia y Santa Cruz, fue la

56. El propietario del título el Marqués de la Lapilla aparece en estas listas en el puesto 136 con una contribución de $12.847,63$ pesetas. Véase CONGOST, Rosa, "Las listas de los mayores contribuyentes de 1875", en Agricultura y Sociedad, $n^{\circ}$ 27, 1983, p. 329. En las fechas de referencia el título nobiliario corresponde a $\mathrm{M}^{\mathrm{a}}$ de las Mercedes Fivaller y Centurión, XII Marquesa de la Lapilla (+ 1896), Grandeza de España. A su muerte tomará el título su hijo, quien fallecerá pronto, siendo designada XIV Marquesa de la Lapilla, su hija, Agueda Martorell y de Fivaller.

57. Véase ALONSO CASTROVIEJO, Jesús Javier, "Los nombres del primer liberalismo logroñés: De Domingo Santa Cruz a Baldomero Espartero", en Historia de la Ciudad de Logroño, T. IV, 1994, pp. 313-316; y del mismo, "La formación de la élite liberal burguesa. Alianzas matrimoniales y desamortizaciones", Brocar, n 19, Logroño, 1995, pp. 211-232.

58. ALONSO CASTROVIEJO, Jesús Javier, Problemática agraria y... pp. 162 y 164.

59. Véase nota $n^{\circ} 57$. Además existe una tesis doctoral recientemente leída en la Universidad de La Rioja de BERMEJO MARTíN, Francisco, Espartero. Hacendado Riojano, Logroño, 1997; donde se aclara definitivamente la privilegiada posición de esta familia a nivel provincial y la biografía más desconocida de Espartero, que se relacionan con los años de residencia en Logroño hasta su muerte y enterramiento en esta ciudad en enero 1879. Agradezco a Francisco Bermejo el original de esta investigación, imprescindible para escribir algunas de estas páginas. 


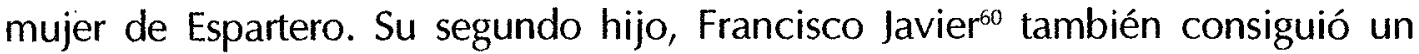
matrimonio ventajoso al casarse con Francisca Ramona García de Tejada, hija de Manuel $M^{a}$ García Gregorio ${ }^{61}$, uno de los mayores propietarios territoriales de la Rioja. De este matrimonio nació Juan Domingo Santa Cruz García. A la muerte de su padre en 1837, él y su tío José Santa Cruz Orive, se hicieron cargo de la casa de Banca "Francisco Javier Santa Cruz", actividad que mantuvieron hasta noviembre de 1868 , en que disolvieron esta sociedad ${ }^{62}$, sin duda afectados por la crisis bancaria que en esta misma fecha se produjo en España. La actividad mercantil del tío y sobrino fue muy amplia (curtidos, tejidos, trujal de aceite), pero no menos importante fue el patrimonio territorial y urbano, que ambos juntos y por separado consiguieron acumular. Mientras el tío estuvo más pendiente de los negocios comerciales, Juan Domingo se ocupó de sus numerosas propiedades territoriales y urbanas, que en estos momentos reunía, los patrimonios de su padre, su abuelo materno Manuel María García Gregorio ${ }^{63}$, fallecido José Santa Cruz el 17 de octubre de 1882 sin heredero directo, su patrimonio se repartió entre sus sobrinos, del que una parte importante le correspondió a Juan Domingo, además de los bienes que el mismo compró en la desamortización de $1855^{64}$.

Genealogía 1. Familia Santa Cruz

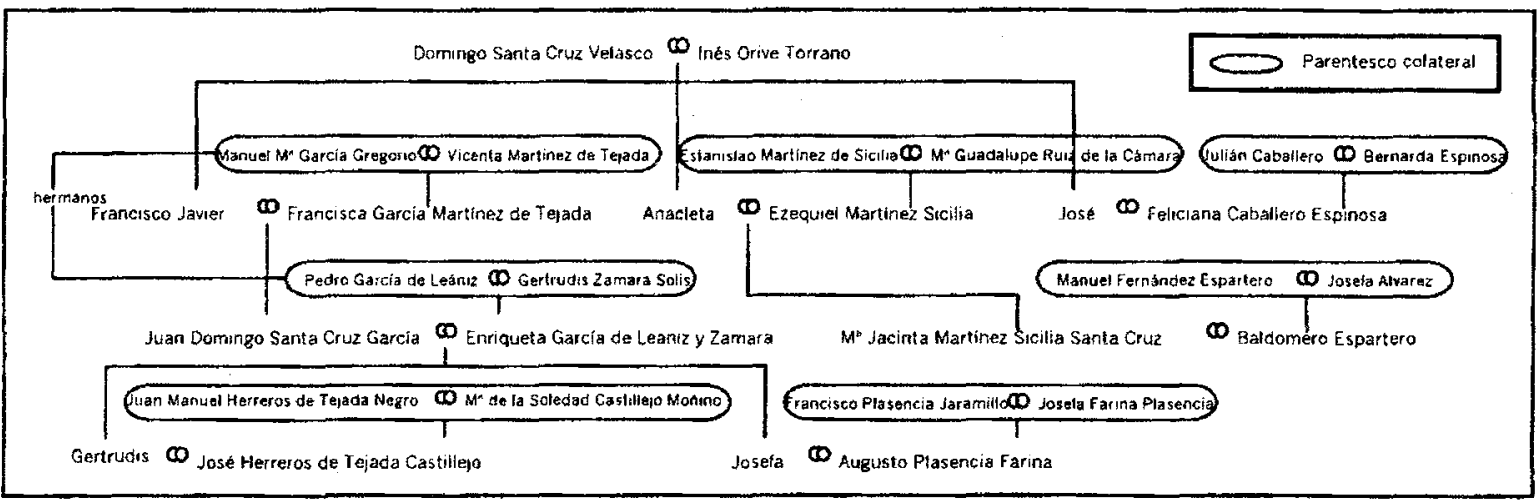

60. Diputado a Cortes por La Rioja en la elección parcial de abril 1836 y en la general de octubre del mismo año, muriendo poco después de haber sido elegido. Véase LOPEZ RODRIGUEZ, Pedro, "La Ciudad de Logroño y sus relaciones con los poderes centrales", Historia de la Ciudad de Logroño, T. IV, 1994, p. 437.

61. Nacido en Laguna de Cameros destacará por sus posesiones territoriales en varias localidades riojanas, aprovechando todas las ptencialidades de la revolución burguesa, fundamentalmente los procesos desamortizadores. Fue Senador electo por la provincia de Logroño en dos ocasiones en el año 1843 (marzo y septiembre).

62. BERMEJO MARTíN, Francisco, Banca, Ahorro y Crédito en Logroño. El sistema financiero riojano entre 1840 y 1950, Logroño, 1990, p. 30, inédito. Agradezco al autor la consulta de esta investigación.

63. A.H.P.L. (Protocolos Notariales), Notario Francisco Javier Muñoz, Leg. 2.251, "Partición de bienes del Sr. Manuel María García", Logroño, Año 1854, ff. 60 y ss. La madre de Juan Dorningo había fallecido el 21 de septiembre de 1824, por lo que todos los bienes del Manuel María García iban a parar a Juan Domingo Santa Cruz.

64. BILBAO DíEZ, Juan Carlos, La desamortización de..., p. 81. 
El último vástago de la familia Santa Cruz, Juan Domingo, ocupó todos los puestos de la representación política provincial ${ }^{65}$, aun cuando las convicciones exaltadas de sus antepasados se fueron atemperando en Juan Domingo, cada vez más cerca de posiciones conservadoras, como veremos en los años de la Restauración cuando fue senador por la provincia, en todas las elecciones celebradas entre 1876 y 1891 . Juan Domingo Santa Cruz García, se había casado con su prima, una rica propietaria sevillana, Enriqueta García de Leaniz y Zamara $^{66}$, con quien había tenido tres hijas: Jacinta, Josefa, casada con el teniente coronel de Artillería Augusto Plasencia Farina, conde de Santa Barbara, vecino de Sevilla; y Gertrudis, también casada con otro militar de cuerpo de Ingenieros, José Herreros de Tejada Castillejo. Tuvo la desgracia de ver morir a todas sus hijas, primero a Jacinta, muerta joven, luego a Josefa en diciembre de 1885, y por último, a su otra hija Gertrudis, en octubre de 1889, unos meses antes, concretamente en mayo, había fallecido su mujer Enriqueta. Cuando él murió el 27 febrero de 1892, los herederos fueron sus nueve nietos, representados por sus padres el Conde de Santa Barbara y José Herreros de Tejada. El mayor patrimonio de la provincia durante el siglo XIX, se dividió y con él se perdió el nombre de los Santa Cruz.

Genealogía 2. Familia Herreros de Tejada

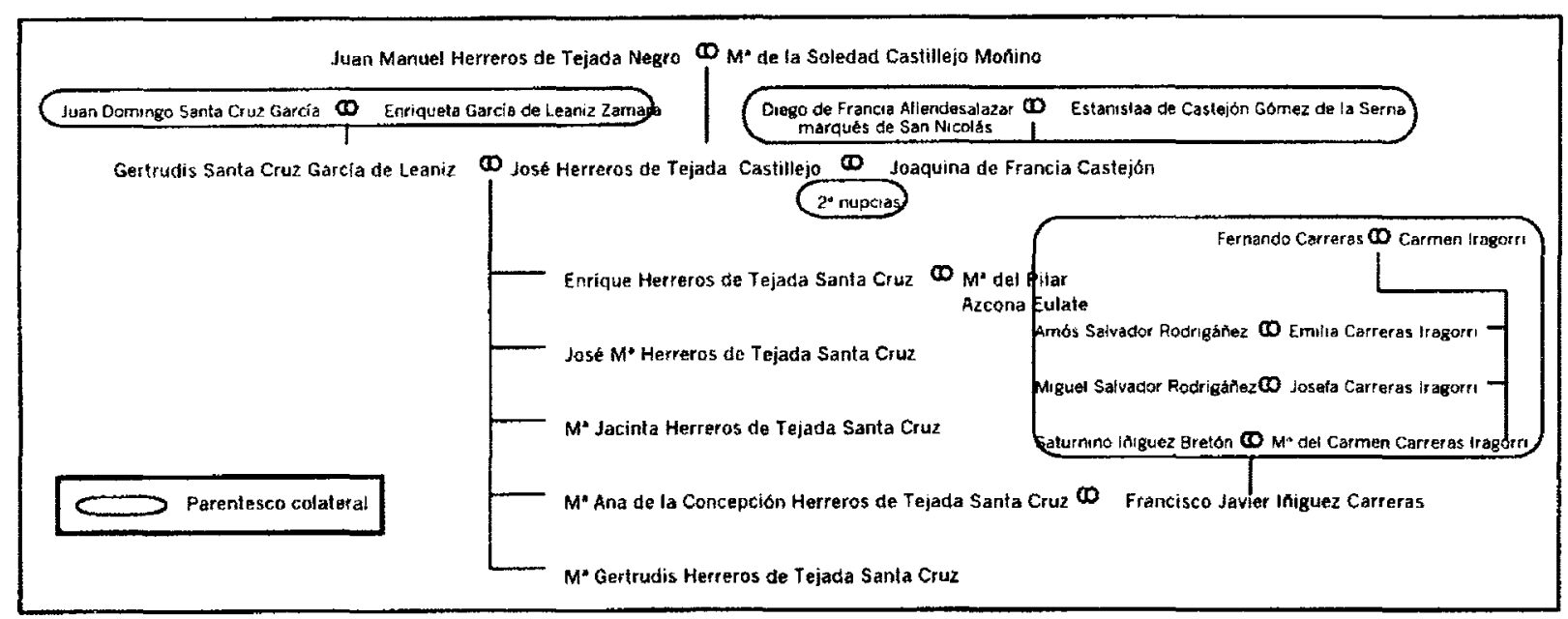

Ahora será el apellido Herreros de Tejada, una de las mayores fortunas privadas de La Rioja, aunque ya no en un lugar tan destacado. Este apellido se vinculó, con otra familia de fuerte raigambre riojana, el Marqués de San Nicolás, cuando en octubre de 1890, justo un año después de la muerte de Gertrudis

65. Lo encontramos como concejal de Logroño en 1841, 1844, 1857, 1863; Diputado provincial (Torrecilla) en 1854; Senador electo (Logroño) en 1871, 1872, 1876, 1877, 1879, 1881, 1886, 1891.

66. Sus padres eran Pedro García de Leaniz y Gertrudis Zamara y Solis. Pedro García de Leaniz era hermano del abuelo materno de Juan Domingo Santa Cruz, Manuel $M^{a}$ García Gregorio. 
Santa Cruz, José Herreros de Tejada, contrae matrimonio con Joaquina de Francia Castejón. En lo político, el apellido Herreros de Tejada ${ }^{67}$, afincado en la provincia a principios de la década de los ochenta, lo veremos en las filas conservadoras, para finalmente durante la Dictadura de Primo de Rivera, representar la tendencia más ultraconservadora, cuando Enrique Herreros de Tejada y Santa Cruz, sea presidente de la Diputación Provincial ${ }^{68}$. Por lo que toca al apellido Plasencia ${ }^{69}$, parece ser que continuaron unos años estrechamente vinculados a Logroño. El mayor de los hijos Augusto Plasencia y Santa Cruz a finales de 1901, en correspondencia de la herencia de su abuelo, Juan Domingo Santa Cruz, hace la declaración de sus propiedades en el término municipal de Logroño. En 1900 el Conde de Santa Barbara soporta una contribución de 1.328,40 pesetas. A partir de 1903 será su hijo el titular de esta contribución que paga en 1905 la cantidad de 1.063,45 pesetas, en 1910 aparece ya como vecino de Sevilla, bajando ostensiblemente su contribución a las 448,73 pesetas, para reducirse en 1920 a las 173,28 pesetas $^{70}$.

Diego de Francia Allendesalazar, marqués de San Nicolás ${ }^{71}$, al comienzo la Restauración, en $1875^{72}$, es el décimo mayor contribuyente de la provincia con $2.580,66$ pesetas, aunque desde principios del siglo XIX, cuando esta familia se instala en Logroño y compra en la desamortización de Godoy 424 fanegas ${ }^{73}$, en poco va a variar su patrimonio territorial a lo largo de la centuria, manteniéndose en los primeros puestos de la representación territorial de La Rioja ${ }^{74}$. También le vemos en la desamortización de Madoz, pujando para completar sus propiedades en Varea ${ }^{75}$. En 1892, aparece con 468 fanegas. En 1900 paga una contri-

67. A.S., HIS-0222-04, doc. 17, Expediente personal de José Herreros de Tejada y Castillejo. Senador por la provincia de Logroño en 1896. Ocupará también destacados puestos en el comité provincial del partido conservador riojano.

68. Véase BERMEJO, Francisco y DELGADO, José Miguel, La Diputación provincial..., p. 465.

69. Augusto Plasencia Farina, conde de Santa Barbará será el inspirador de la "Cocina Económica", institución benéfica constituida en 1894, para dar auxilio a los pobres. Desde el punto de vista político llegará a ser candidato a senador por el partido conservador en las elecciones de 1899, aunque no resultará elegido.

70. A.H.P.L. (Hacienda), Leg. 4.064 a 4.068, Repartimientos de contribución rústica $y$ pecuaria de la ciudad de Logroño, 1900-1931. La mayoría de los datos sobre contribución que aparecen en este capítulo están sacados de estos legajos, por lo que a partir de ahora no citaré la fuente.

71. El primer marqués de San Nicolás fue Nicolás Francia Pascual, natural de Briones (La Rioja) donde nació en 1696 (+ Madrid, 1766), Tesorero General del Reino en la época del Marqués de la Ensenada, le fue concedido el título en 1761, para premiar sus servicios a la Corona. Véase GARRÁN, Constantino, Cien Riojanos Ilustres de los siglos XVIII y XVIII, original manuscrito, Logroño, 1907.

72. CONGOST, Rosa, "Las listas de los mayores...", p. 354. Siempre que hagamos referencia a esta fecha, nos estaremos refiriendo a esta fuente.

73. ALONSO CASTROVIEJO, jesús Javier, Problemática agraria y..., p. 146.

74. Véase Cuadro 7, p. 23.

75. BILBAO DÍEZ, Juan Carlos, La desamortización de..., pp. 78-79. 
bución de 1.534,67 pesetas y en 1915 su hijo Ricardo es el segundo mayor contribuyente territorial de Logroño, con una cuota de contribución cercana a las 1.200 pesetas $^{76}$, en 1931 aparece en la lista de mayores contribuyentes de la provincia con una cuota de $1.696,39$ pesetas $^{77}$. En cuanto a la actividad política el padre de Diego, Joaquín de Francia, fue el primer alcalde constitucional que tuvo Logroño, y él será también varias veces alcalde de la Capital y diputado provincial, tras el golpe de estado del General Pavía, destacado dirigente del partido conservador, llegará a ocupar la presidencia provincial del partido, consiguiendo ser alcalde incluso en la época en que los liberales controlaban la provincia $^{78}$. De su matrimonio con Estanislaa de Castejón y Gómez de la Serna, hija del Marqués de Fuerte-Gollano, gran propietario de Logroño, tiene cuatro hijos, el primogénito Ricardo de Francia Castejón, heredó el título a la muerte del Marqués, el 26 de julio de 1903. Este llegó a ser diputado provincial en 1896 y presidente de la Diputación en $1907^{79}$. A su muerte en diciembre de 1922 el título nobiliario pasó a la familia Herreros de Tejada.

La familia Castejón, cuyo origen se rastrea en el vecino País Vasco, concretamente en San Sebastián donde nace Gregorio $M^{a}$ de Castejón, marqués de Fuerte-Gollano y de Velamazán. En la década de los treinta del siglo XIX aparece el poseedor del título como regidor preeminente del Ayuntamiento de la capital y a mediados de la centuria paga una contribución de 5.437 pesetas ${ }^{80}$. Representa a aquella nobleza terrateniente que a partir del siglo XIX, va perdiendo liquidez y a pesar de que mantiene sus propiedades, se encuentra profundamente endeudada. Casado con Agapita Gómez de la Serna, natural de la población de Oyón (Alava), consigue ventajosos matrimonios para sus nume-

76. LÓPEZ RODRÍGUEZ, Pedro, Sociedad riojana y..., Cuadro II.11, p. 57. Véase Cuadro 9, p. 44 . Las diferencias que se observan en la contribución se deben a que el cuadro no incluye un porcentaje que la Delegación de Hacienda cargaba para atender los gastos de la enseñanza primaria, una cifra que oscila en todo el período en torno al $16 \%$ de la contribución rústica y pecuaria.

77. Véase BERMEJO MARTÍN, Francisco y DELGADO IDARRETA, José Miguel, La Diputación provincial..., pp. 344-345. Cuando hagamos referencia a esta fecha, nos referiremos siempre a esta fuente.

78. La última vez en la que el Marqués de San Nicolás se presentó a unas elecciones municipales, fue en la convocatoria de mayo de 1891. Los liberales trataron de impedir su candidatura. Ante tal hecho, el Marqués decidió presentarse como concejal por todos los distritos de Logroño, obteniendo la mayoría en todos ellos. Los liberales tuvieron que reconocer su victoria, ocupando la alcaldía entre 1891 y 1895 . Agradezco a Mª Luisa García Arriaga la posibilidad de consultar su tesis doctoral inédita: El Ayuntamiento de Logroño en la Regencia de $M^{a}$ Cristina (1885-1902), vol. 2, Universidad de Deusto, 1992, pp. 383 y ss; de la que han sido tomados estos datos. Las otras ocasiones en que había sido Alcalde de Logroño fue durante los períodos 1866-68, 1875-81 y diputado provincial por Briones en 1874.

79. Véase BERMEJO MARTíN, Francisco y DELGADO IDARRETA, José Miguel, La Diputación provincial..., pp. 436.

80. B.O.P.L. Suplemento del año 1852, Repartimientos de la Contribución de la provincia de Logroño. 
rosos hijos, una de sus hijas contrajo matrimonio con el Conde del Real, grande de España. Su hija Joaquina se casó con Ricardo López Montenegro García del Valle, natural de Villoslada de Cameros (La Rioja) y otro de los grandes propietarios de la provincia. La arriba mencionada Estanislaa de Castejón casada con Diego de Francia, marqués de San Nicolás. El apellido Castejón continua en su hijo Fermín de Castejón y Gómez de la Serna, que contrae matrimonio con Juana Martínez de Velasco, su nombre aparece en las listas de mayores contribuyentes de la provincia a partir de la década de los setenta, aunque no en los primeros lugares, sino en posiciones bastante retrasadas, en 1875 en el trigésimo quinto lugar con una contribución de 1.212 pesetas $^{81}$. Su participación política es escasa, aunque en los ayuntamientos de 1867 y 1874 aparece como concejal y tercer teniente de alcalde de Logroño. En 1898 cuando fallece Fermín Castejón, en su inventario de bienes, las deudas son mayores que los bienes inventariados, "atendiendo a la crisis que atraviesa dicha propiedad agraria por sus escasos productos y malas ventas" ${ }^{\prime 82}$. En la relación de los veinte mayores contribuyentes por propiedad rústica de la Capital, en 1915, los herederos de Fermín Castejón soportan una contribución de 684,15 pesetas, alcanzando las 807,24 pesetas en 1925.

Genealogía 3. Familias Marqués de San Nicolás-Marqués de Fuerte-Gollano

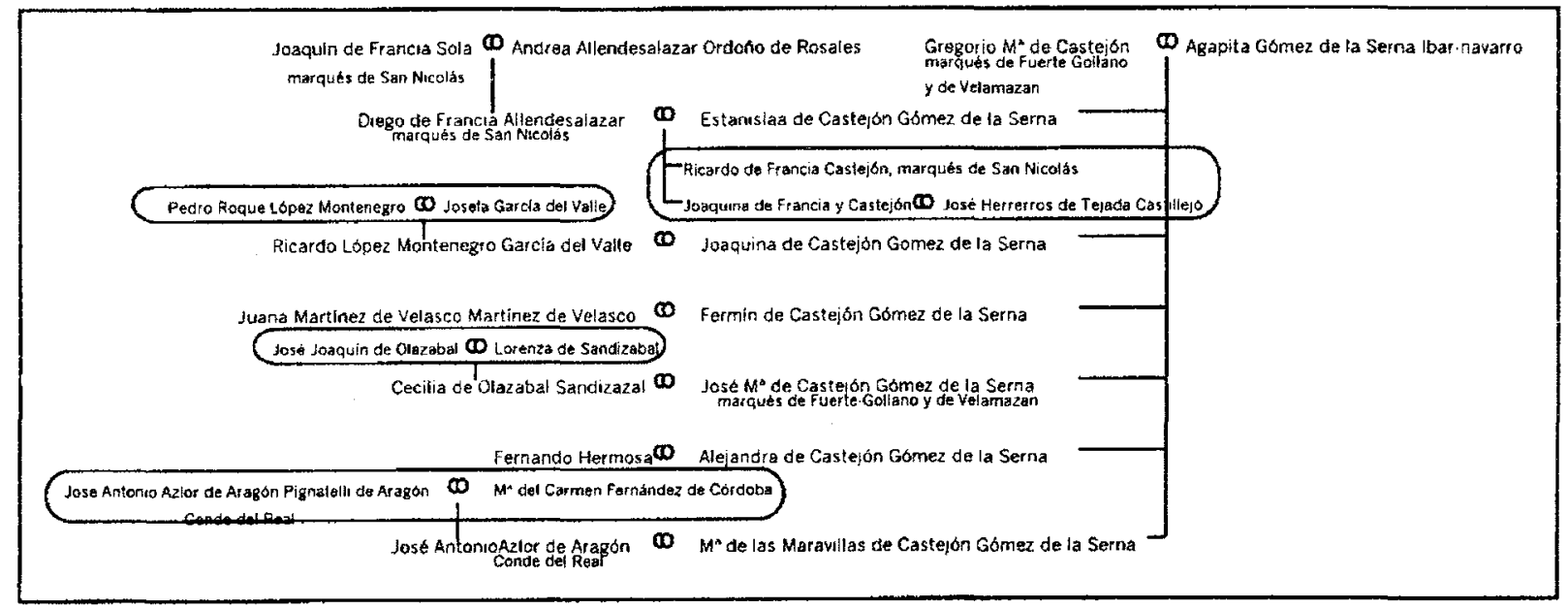

Otro título nobiliario que aparece como uno de los mayores propietarios de Logroño, los herederos de la Marquesa de la Habana. La señora Vicenta Fernández Luco y Santa Cruz, casada con José Gutiérrez de la Concha e Irigoyen, marqués de la Habana (1857), grande de España (1864) y político destacado

81. B.O.P.L. $\mathrm{n}^{\mathrm{0}} 124$, p. 1160,1875 , Lista de los 50 mayores contribuyentes de la provincia por contribución territorial.

82. A.N.R.M. (Protocolos Notariales), Notario Plácido Aragón, nº 183, ff. 563-635 v., Logroño, 2 mayo de 1899, f. 613. 
durante el reinado de Isabel II, llegando a ser presidente del gobierno durante un corto espacio de tiempo justo antes del proceso revolucionario de 1868 . Su relación con Logroño viene de la mano de su mujer, unida por lazos familiares con la mujer de Espartero. José de la Concha fue diputado a Cortes por La Rioja en 1845, igual que sus yernos el Conde de Xiquena y el Conde de Torrejón, en varias ocasiones durante el reinado de Isabel $\mid \|^{83}$. A partir de la Restauración, la relación de esta familia con La Rioja, va a ser mucho menor, sólo en 1876, por última vez, el Conde de Xiquena va a resultar elegido diputado a Cortes por esta provincia. Buena parte de sus posesiones riojanas las recibe por herencia de la mujer de Espartero, que muere sin descendencia. Es el característico caso de la nobleza rentista, que vive en Madrid y cuida de sus propiedades un administrador $^{84}$. En 1900 pagaba una contribución de 1.847,44 pesetas, a partir de la década de los diez parece ser que su patrimonio se divide entre sus herederos que contribuyen de manera individualizada, la contribución que pagan en 1915 es tan solo 507,89 pesetas y 280,60 en $1925^{85}$.

Genealogía 4. Familia Marqués de la Habana

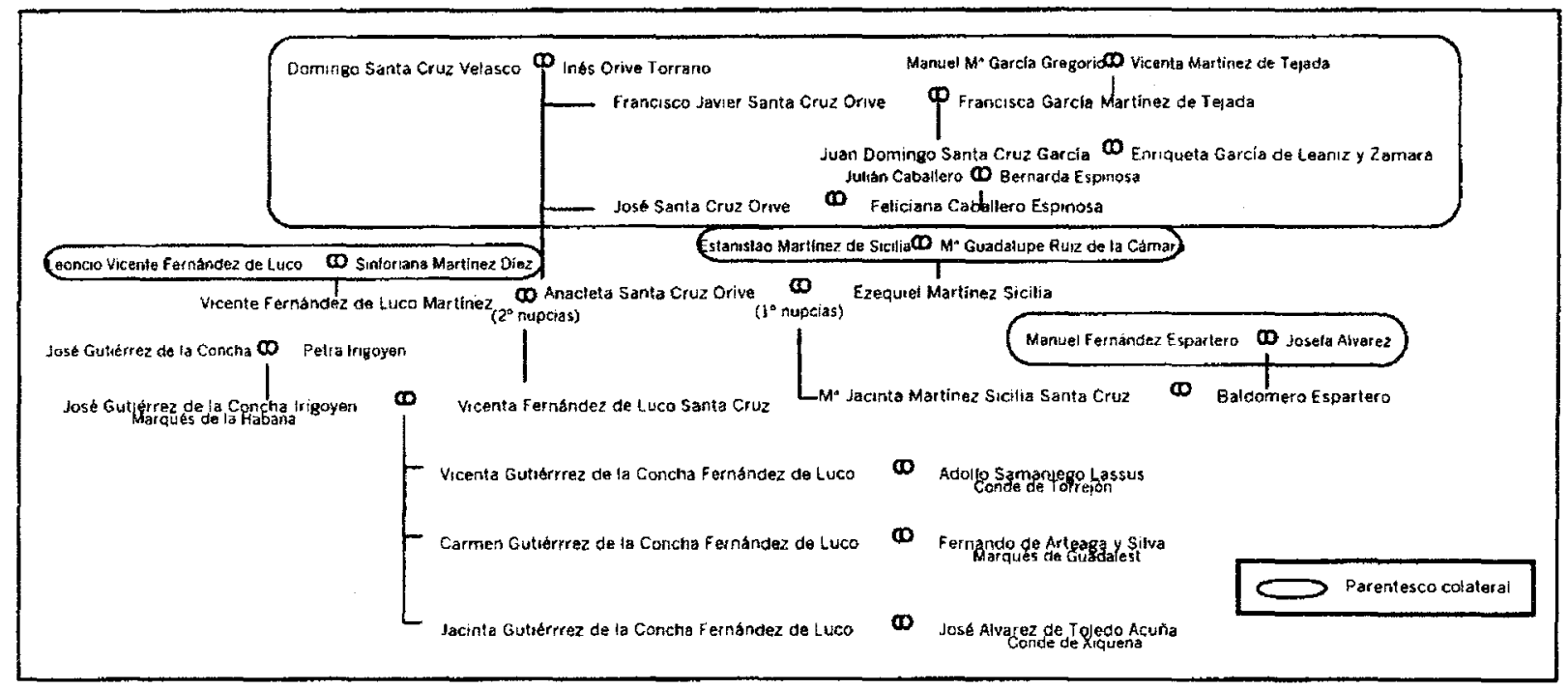

Continuando con la descripción de los mayores propietario de Logroño de origen nobiliario, hay que destacar a otra familia no menos importante que la

83. Véase LÓPEZ RODRíGUEZ, Pedro, "La ciudad de Logroño...", T. IV, p. 437.

84. El administrador de sus propiedades es Pascual Velázquez Francisco, concejal del Ayuntamiento de Logroño en 1893 y 1897, que tiene como más destacados hechos el ser el primer concejal del Ayuntamiento de Logroño elegido de manera consecutiva en dos ocasiones, gracias a la ley Mellado de agosto de 1896 que permitía la reelección en aquellas poblaciones menores de 100.000 habitantes. Por otra lado, en julio de 1899 fue depuesto como concejal del Consistorio logroñés, tras demostrar su implicación en un fraude, al traficar con productos sin pagar el correspondiente impuesto de consumos.

85. A.H.P.L (Hacienda), Leg. 4.066 al 4.068 Repartimiento de contribución rústica y pecuaria de Logroño, varios años. Véase Cuadro 9, p. 44. 
anteriormente citada, me estoy refiriendo al apellido Orovio. La relevancia económica y política de esta familia de origen alfareño, se rastrea desde inicios del siglo XIX ${ }^{86}$. Tiene su más destacado representante en la figura de Manuel Orovio Echagüe (1817-1883), marqués de Orovio (1868) y personaje político de primer orden durante el reinado de Isabel II y el inicio de la Restauración ${ }^{87}$. Pero aquí nos interesa, su única hija y heredera, Isabel Orovio Fernández Urrutia, vecina de Alfaro, que reúne los patrimonios de estas dos familias de grandes propietarios riojanos. Esta contrae matrimonio con otro destacado propietario y diputado a Cortes por Torrecilla, Francisco Javier de Eulate y Moreda ${ }^{88}$, quien fallece el 10 de abril de 1884, a los siete años de contraer matrimonio, dejando como único descendiente a Manuel de Eulate Orovio. Ambos juntos y por separado reúnen unos de los mayores patrimonios territoriales de La Rioja, sin contar con las numerosas propiedades que la familia Fernández Urrutia tiene en Logroño ${ }^{89}$ y que con motivo del fallecimiento del gran propietario y exgobernador civil de la provincia, Vicente Fernández Urrutia y Benito del Valle en 1881 se dividió entre sus seis hijos. Desde comienzos del siglo XX, la evolución de las contribuciones, demuestran que este patrimonio va perdiendo importancia en Logroño, aunque no a nivel provincial, ya que en 1931, la Marquesa de Orovio todavía es una de las mayores contribuyentes de la provincia, con una contribución de $2.948,82$ pesetas $^{90}$.

86. Véase BERMEjO MARTíN, Francisco y DELGADO IDARRETA, José Miguel, La Diputación provincial..., pp. 349-350.

87. BERMEJO MARTíN, Francisco, "Olózaga y Orovio o el caciquismo en el Distrito riojano de Arnedo: 1846-1864", en Actas del Segundo Coloquio sobre Historia de la Rioja, Colegio Universitario de La Rioja, Logroño, 1986, pp. 341-364.

88. El primer miembro de esta familia el gaditano Rafael Eulate Acedo fue diputado provincial por Torrecilla en cuatro ocasiones entre 1858 y 1865. Sus dos hijos José María y el mencionado Francisco Javier Eulate Moreda, serán diputados a Cortes por el distrito de Torrecilla durante la Restauración, en dos ocasiones cada uno por el partido conservador. Jose María, amigo personal de Romero Robledo, será diputado por esta tendencia en las elecciones de 1896. En 1852 como vecino de Logroño Rafael Eulate paga una contribución de 1.963,06 pesetas. El apellido Eulate reúne en 1892 una cantidad de tierra en torno a las 300 fanegas, el máximo beneficiario de esta propiedad será Manuel de Eulate Orovio. Otros miembros de esta familia como José $M^{a}$ y Cristina Eulate Moreda pagan también importantes contribuciones a principios de este siglo.

89. A.H.P.L. (Hacienda), Leg. 4222, Amillaramiento de la ciudad de Logroño de 18921893. La propiedad territorial de los Fernández Urrutia en Logroño, según esta fuente, se encuentra en torno a las 500 fanegas de tierra.

90. Véase BERMEJO MARTíN, Francisco y DELGADO IDARRETA, José Miguel, La Diputación provincial..., Cuadro I, p. 345. 
Genealogía 5. Familias Orovio-Fernández Urrutia

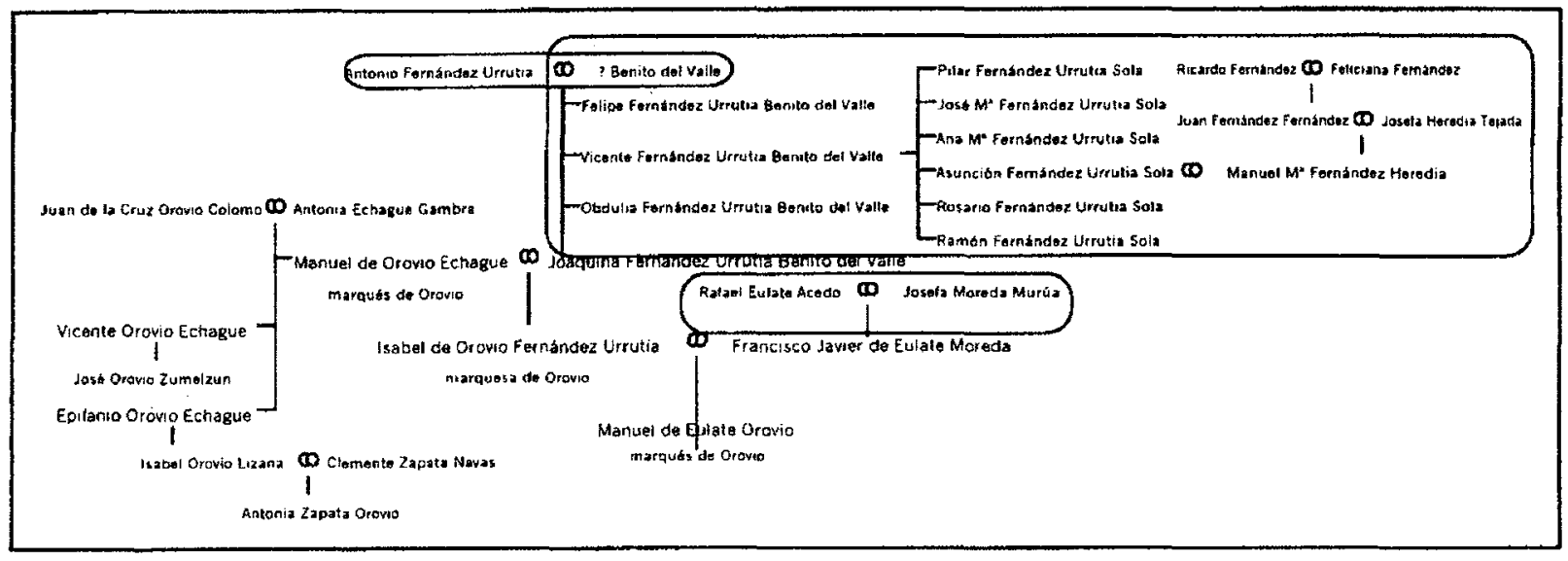

Genealogía 6. Familia Eulate

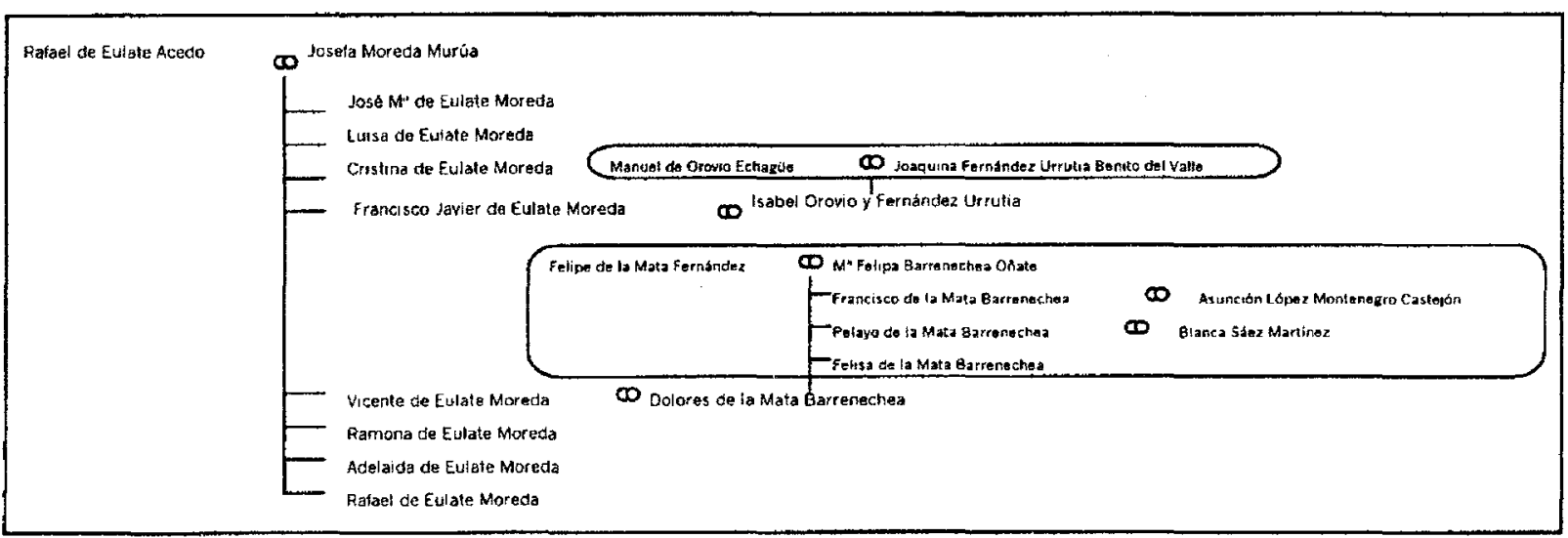

El siguiente apellido, también con un título nobiliario, corresponde a Luciano Murrieta García, Marqués de Murrieta ${ }^{91}$, ayudante de campo del General Espartero y residiendo durante largas temporadas en su propia casa, aunque estaba domiciliado en Madrid. Destacado bodeguero, fue uno de los principales promotores en la introducción de los modernos sistemas de vinificación, para la elaboración del vino de Rioja desde, su finca de "Igay"

91. Entronca directamente con una de las mayores fortunas españolas del siglo XIX, cuyo patrimonio se formó gracias al comercio de vino y azúcar, entre España y su colonia cubana, y que después se instaló en Londres, centro del comercio mundial. Véase BAHAMONDE, Angel y CAYUELA, José, Hacer las Américas.- Las élites coloniales españolas en el siglo XIX, Alianza, Madrid, 1992, pp. 94-95. Parece ser, por los datos aportados por D. Pedro González, el Marqués de Murrieta es hijo de Francisco Murrieta Arias, natural de Santurce (Vizcaya) y Mariana García Lemoine, nacida en Perú. Francisco Murrieta es primo carnal de Cristóbal Murrieta, al que se refiere Angel Bahamonde en su estudio.

92. GARCÍA SANTAMARIA, Pedro y MARTín LOSA, Francisco, EI Rioja y sus viñas, Logroño, 1982, pp. 22-24. 
traslada su residencia a Logroño, donde vivió hasta el final de sus días, en noviembre de 1911. El séptimo mayor propietario de Logroño en 1892, satisface en 1900 una cuota de 1.155,85 pesetas, antes de su muerte en 1910 paga una cuota de 1.542,71 pesetas. Su heredero Julián de Olivares Baldivián, Conde de Artaza, se presenta en 1915 como el mayor propietario de Logroño, al satisfacer una contribución de $1.673,24$ pesetas, que alcanzaron las $2.073,60$ pesetas en 1925. En 1931 el Conde de Artaza es el noveno mayor contribuyente de la provincia de Logroño, con una cuota de $3.349,73$ pesetas. El nombre del Marqués no aparece vinculado directamente a la política, aunque formó parte de las principales instituciones o sociedades constituidas en la Capital, sobre todo, de aquellas relacionadas con la agricultura, como pueden ser la organización de la Exposición Regional de Agricultura de 1897; o sociedades benéficas, a él se debe la creación de la "Casa Cuna del Niño Jesús", inaugurada en 1906

El siguiente gran propietario es Felipe de la Mata Fernández, casado con María Barrenechea Oñate, hija del Conde de San Cristóbal y Marqués de Vargas, y hermana del diputado a Cortes por Logroño a comienzos de la década de los setenta del siglo XIX, el liberal-demócrata Francisco Barrenechea Oña$\mathrm{te}^{94}$. Felipe de la Mata Fernánde ${ }^{95}$, nacido en Corera (La Rioja), donde tiene su origen esta familia, e hijo único de otro gran propietario, Hilario de la Mata, nacido en Cartagena de Indias (Colombia), que aparece en 1836 pagando una contribución de 2.095 pesetas. Felipe contribuye en 1860 con 3.136 pesetas y en 1875 aparece en sexto lugar de la lista de mayores contribuyentes de la provincia, cotizando 3.020,40 pesetas. En el amillaramiento de 1892 registra una propiedad rústica de 322 fanegas, que le sitúan en el decimocuarto lugar por la cantidad de tierra que posee, aunque para esta fecha, Felipe de la Mata había fallecido el 28 de diciembre de 1887. Sus propiedades se van a repartir entre sus hijos ${ }^{96}$ : Dolores de la Mata Barrenechea, casada con Vicente Eulate Moreda, Francisco de la Mata Barrenechea, casado con María Asunción López Montenegro y Castejón, Pelayo de la Mata Barrenechea, esposo de Blanca Sáez Martínez y la hija menor del matrimonio, Felisa. Las dos hijas trasladaron pronto su residencia a Bilbao, donde también residió durante unos años Francisco hasta la muerte de su esposa en 1891, el fruto de este matrimonio fue Felipe de la Mata y López Montenegro. A partir de estos años Francisco inicia su participación política, sin una adscripción muy clara en sus inicios, comenzó en posiciones cercanas al partido liberal, para finalmente integrarse en el grupo

93. GARCÍA ALCALDE, Pablo, "Una institución benéfica municipal riojana. La Casa Cuna del Niño Jesús", Berceo, n 120, Logroño, 1991, pp. 117-123.

94. LÓPEZ RODRÍGUEZ, Pedro, "La ciudad de Logroño...", T. IV, p. 442.

95. Diputado provincial por Arnedo en 1863. El apellido Fernández corresponde a otra familia de grandes propietarios de la zona de Corera, uno de cuyos miembros Braulio Fernández y Fernández Arnedo será diputado a Cortes por Logroño en las elecciones de 1879.

96. A.H.P.L. (Protocolos Notariales), Notario Plácido Aragón, Leg. 8.575, "Partición de bienes de Felipe de la Mata Fernández", Logroño, 3 de noviembre de 1888, ff. 2111-2221. 
conservador, siendo alcalde de Logroño a caballo de los siglos XIX-XX, y uno de los pocos diputados a Cortes por este partido, cuando obtuvo la representación por el distrito de Nájera-Torrecilla en las elecciones de 1907, ocupó también la presidencia regional de este partido ${ }^{97}$. Su hermano Pelayo, también participó desde las filas conservadoras en la política provincial a comienzos del siglo XX, llegando a ser concejal del Ayuntamiento de Logroño en $1915^{98}$, presentando su candidatura a las elecciones de diputados, sin mucho éxito, su talla política se demostró muy inferior a la de su hermano.

Genealogía 7. Familias Barrenechea-de la Mata

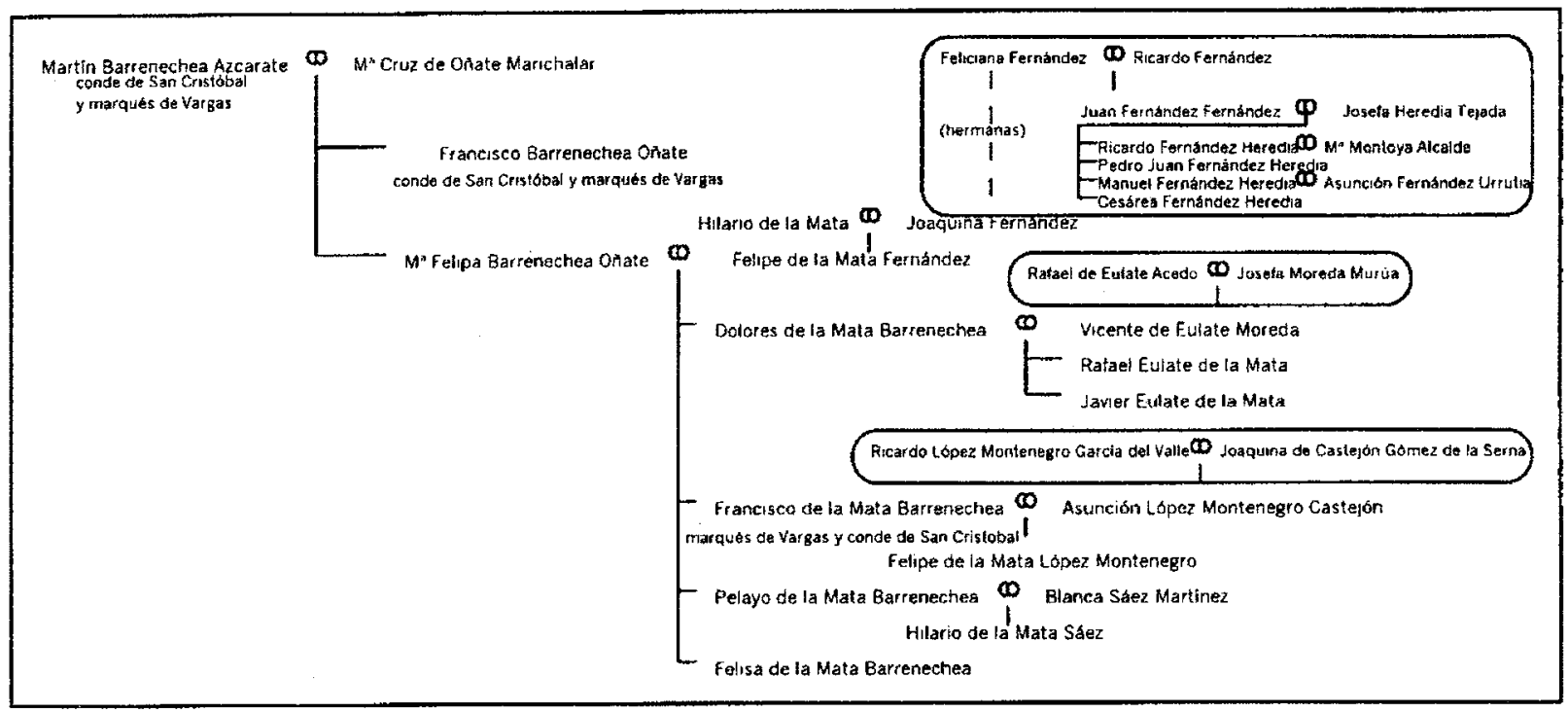

Siguiendo con la nómina tenemos a los herederos del propietario Casimiro Miguel y Soret, que será diputado provincial por el distrito de Arnedo durante el reinado de Isabel II. En el año 1860 soporta una contribución de 2.630 pesetas. Casado con Josefa Guarro Soret, tiene tres hijos, Juan Manuel, Rufina y Dionisio $M^{a}$ Miguel y Guarro. A su muerte el 9 de julio de 1863, todos ellos son los perceptores de la herencia, pero su hijo Dionisio fallece tres años más tarde, su esposa Josefa, en enero de 1880, y su otro hijo Juan Manuel casado con la hermana de Jose Rodríguez Paterna, Juana Rodríguez Paterna y Gilberte, muere en septiembre de 1886. Por todo ello quedaran como únicos herederos la hija soltera Rufina de Miguel y Guarro y el hijo de Juan Manuel, el abogado José $M^{a}$ de Miguel y Rodríguez Paterna ${ }^{99}$. En 1892 los herederos de Casimiro

97. SÁENZ CENZANO, Salvador, "Apuntes históricos de Logroño. Vida y obra de tres alcaldes distinguidos", Berceo, Año III, $n^{\circ}$ 7, Logroño, 1948, pp. 183-187.

98. LÓPEZ RODRÍGUEZ, Pedro, Sociedad riojana y..., Cuadro IV.20, pp. 114.

99. A.H.P.L. (Protocolos Notariales), Notario Félix Martínez Verde, Leg. 7.513, "Escritura de división de herencia otorgada por Doña Josefa Guarro y Soret, Don Juan Manuel y Doña Rufina Miguel y Guarro", Logroño, 26 de junio de 1876, ff. 477-519 v. Notario Plácido Aragón, Leg. 
Miguel y Soret registran una propiedad de 265 fanegas. En la lista de 1915 de los veinte mayores contribuyentes por propiedad rústica de Logroño, aparecen en decimoséptimo lugar, con una contribución territorial de 387,54 pesetas, cantidad que asciende a 485,40 pesetas en 1925.

Genealogía 8. Familia Rodríguez Paterna

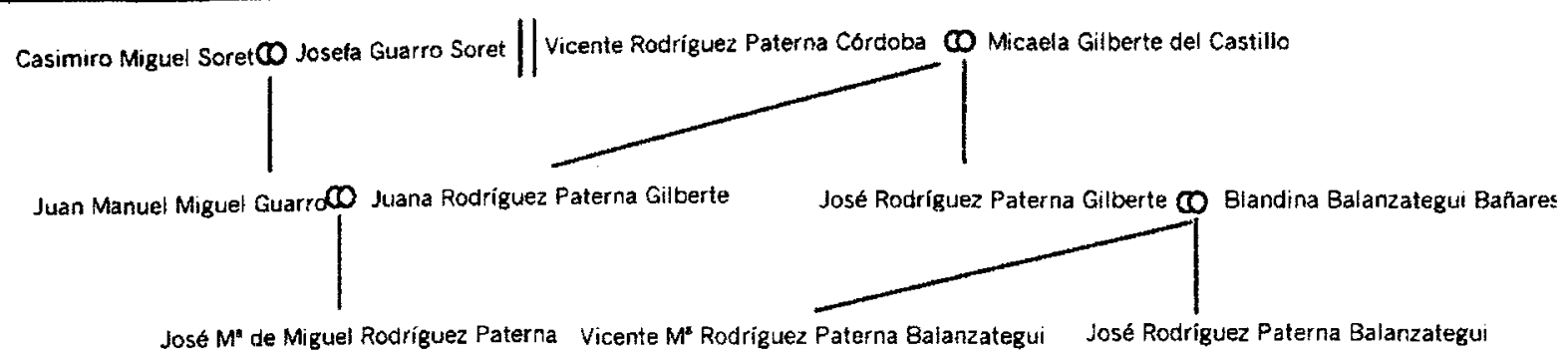

Por su relación con la anterior familia, vamos a analizar a los Rodríguez Paterna, originarios de la localidad albaceteña de Almansa. Vicente Rodríguez Paterna y Córdoba, contrae matrimonio con la logroñesa Micaela Gilberte del Castillo. De este matrimonio nacen dos hijos: José Rodríguez Paterna y Gilberte, casado con Blandina Balanzategui Bañares, hija de un rico propietario de la localidad alavesa de Elciego y Juana Rodríguez Paterna, casada con el anteriormente mencionado Juan Manuel de Miguel Guarro. José Rodríguez Paterna, tuvo cuatro hijos, de los que sólo sobrevivieron Vicente $M^{a}$ y José Lorenzo Rodríguez Paterna y Balanzategui. El amillaramiento de 1892 sitúa a José Rodríguez Paterna como el segundo mayor propietario de Logroño, con unas posesiones de 1.427 fanegas. En 1915 su hijo Vicente $M^{a}$ Rodríguez Paterna y Balanzategui soporta una contribución rústica en Logroño de 794,64 pesetas, que será de 2.064,10 pesetas en 1931, donde aparece como uno de los mayores propietarios de la provincia. En el plano político el titular de la familia, Vicente Rodríguez Paterna y Córdoba fue diputado provincial por Logroño en 1866, aunque será su hijo José Rodríguez Paterna, de ideología conservadora, el más recordado, por ocupar la alcaldía de Logroño de manera consecutiva entre 1885 y $1891^{100}$. Presidente de distintas entidades agrícolas riojanas, como la "Cámara Agrícola Riojana" (1894), de la que fue miembro fundador; y de diversas sociedades recreativas logroñesas como el "Círculo Logroñés" o el de "La Amistad". Alcalde durante la epidemia de cólera de 1885, donde perdió una de sus hijas, siendo condecorado con la Gran Cruz de Isabel la Católica y la de Carlos III. El hijo de éste Vicente Rodríguez Paterna, fue concejal y tenien-

8.575, "Inventario de bienes de Josefa Guarro y su hijo Juan Manuel de Miguel", Logroño, 19 de diciembre de 1888, ff. 2.686-2722.

100. SÁENZ CENZANO, Salvador, "Vida y obra de...", pp. 178-181. 
te de alcalde del mismo Ayuntamiento al ser elegido en los comicios municipales de $1915^{101}$.

Lucas Rodrigáñez Mateo Sagasta, es el cuarto máximo propietario de Logroño según el amillaramiento de $1892^{102}$. Hijo de Celedonio Rodrigáñez Austria y $M^{a}$ del Carmen Mateo Sagasta, hermana de Clemente Mateo Sagasta, padre éste de Práxedes Mateo Sagasta. Hermano de Hipólito Rodrigáñez Mateo Sagasta y tío de Tirso Rodrigáñez Sagasta -véase genealogía 9-. Lucas Rodrigáñez que no ocupa ningún cargo político stricto sensu, fue durante muchos años Delegado del Banco de España en Logroño. Satisface en 1865 una contribución de 460 pesetas, mientras que su hermano Hipólito paga en igual fecha 722 pesetas. En 1880, Lucas Rodrigáñez paga igual cantidad al Fisco, que en 1865. Contrae matrimonio ya mayor con Rosa Fouché, natural de la localidad francesa de Angulema. El beneficiario de la herencia será el hijo de ésta, el comerciante y concejal, Eugenio Amalric Fouché, casado con Asunción Rivas Iñiguez, hija de Policarpo Rivas Vidaña, a la sazón hermano de Nicanor Rivas Vidaña, diputado y presidente de la Diputación provincial durante varios años. Eugenio Amalric recibe entre otros títulos el de Comendador de la orden civil del Mérito Agrícola, ex-comisario regio de Fomento. En 1915 satisface 450,41 pesetas de contribución.

Genealogía 9. Familia Rodrigáñez-Sagasta

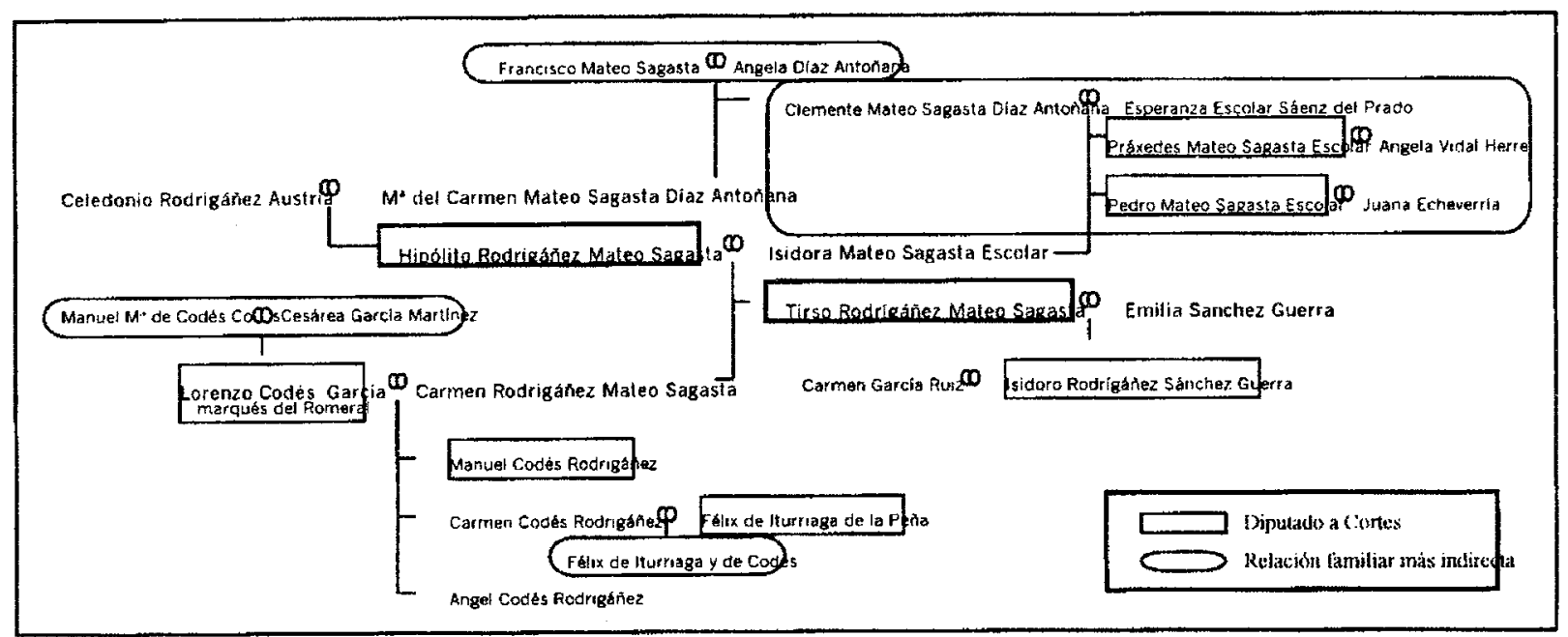

El sexto mayor propietario de Logroño en 1892, con 820 fanegas de tierra es Lorenzo Codés García, marqués del Romeral, natural de la aldea de El Horcajo de la localidad riojana de Lumbreras. Casado con Carmen Rodrigáñez Sagasta, hermana de Tirso Rodrigáñez y Sagasta y, por tanto, también relacio-

101. LÓPEZ RODRÍGUEZ, Pedro, Sociedad riojana y..., Cuadro IV.20, pp. 114.

102. Véase Cuadro 7, p. 23. 
nado con Práxedes Mateo Sagasta -véase genealogía 10-. El título nobiliario procede de su tío y primer marqués del Romeral, Manuel Martínez Pérez, a quien le fuera concedido por Amadeo de Saboya el 27 de diciembre de $1872^{103}$. La relevancia económica de esta familia puesta de manifiesto al manejar los protocolos notariales en las operaciones testamentarias de partición de bienes, es equiparable a su importancia política. Controlan políticamente el distrito de Torrecilla, donde consiguen la mayoría de las actas de diputado a Cortes por el distrito, desde la década de los setenta del siglo XIX, hasta que el último de los representantes de la familia el ingeniero de caminos Félix de Iturriaga de la Peña obtiene su última acta en los comicios de $1916^{104}$. Lorenzo Codés García, parece ser, hizo su fortuna personal en Méjico, donde muy joven emigró y se dedicó al comercio. A su regreso se instaló en Logroño, dedicándose a la política, representando al distrito de Torrecilla entre 1881 y 1901, en que resultó elegido por última vez, ocupando en varias ocasiones la presidencia provincial del partido liberal y la presidencia de la Diputación Provincial, cargó que representaba cuando falleció el 28 de febrero de $1907^{105}$. En cuanto a su situación económica satisfizo en 1900 una contribución rústica de 508,91 pesetas, que fue de 441,44 pesetas en 1905. Su yerno Félix de Iturriaga de la Peña, casado con su hija Carmen de Codés y Sáenz Rodrigáñez, contribuye en la capital con 424,07 pesetas en 1915, aumentando en 1925 hasta las 551,20 pesetas.

Estos son los nombres más destacados que aparecen en la lista de los mayores propietarios de la ciudad de Logroño, según el amillaramiento de 1892. Pero la nómina es corta para expresar la verdadera extensión y representatividad de la propiedad territorial en el municipio logroñés, de ahí la elaboración del Cuadro 9 donde se recogen todos aquellos cuya propiedad supera las 100 fanegas. Son alrededor de unas 30 personas $^{106}$, que podríamos considerar mediana propiedad

103. A.S., HIS- 0390-05, Expediente personal del senador Manuel Martínez Pérez, marqués del Romeral. Senador de la provincia de Logroño en 1881 y A.H.P.L., (Protocolos Notariales), Notario Plácido Aragón, Leg. 7.467, "Descripción, liquidación y adjudicación de bienes a la muerte de D. Manuel Martínez Pérez, Marqués del Romeral", Logroño, 8 de julio de 1882, ff. 661-696.

104. El primer marqués del Romeral, Manuel Martínez Pérez es elegido diputado a Cortes por este distrito en las elecciones de 1871 y abril de 1872. Su sobrino Antonio Rodriguez García, segundo Marqués del Romeral es elegido por el mismo distrito en las elecciones de agosto de 1872. El tercer marqués del Romeral, Lorenzo Codés García representa al distrito entre 1881 y 1901 . A este le sustituye su yerno Félix de Iturriaga, que obtiene el acta de diputado entre 1903 y 1916. En 1918 se presenta a los comicios, aunque esta vez por el partido conservador, perdiendo el acta ante el candidato liberal. El hijo de Lorenzo Codés, Manuel Codés Rodrigáñez consigue el acta de diputado por el distrito de Arnedo en 1905.

105. Diputado a Cortes (Torrecilla) 1881, 1886, 1891, 1893, 1898, 1899, 1901. Diputado Provincial (Najera) 1905. Presidente de la Diputación Provincial abril 1905 a abril 1907. Senador electo (Logroño) 2 septiembre 1881. Presidente del Comité provincial del partido liberal tras la muerte de Nicanor Rivas en 1889.

106. A partir de ahora es conveniente tener cerca el Cuadro 9, pp. 44-45, fundamental para seguir a estos propietarios y la evolución de sus contribuciones. Este cuadro se ha elaborado tomando como base el Amillaramiento de 1892-1893, con las propiedades allí declaradas. 
por el volumen de tierras que poseen, aunque para muchos de ellos la propiedad rústica representa sobre todo una fuente de renta y de prestigio social. En las siguientes páginas voy a destacar alguna de estos personajes.

Genealogía 10. Familia Marqués del Romeral

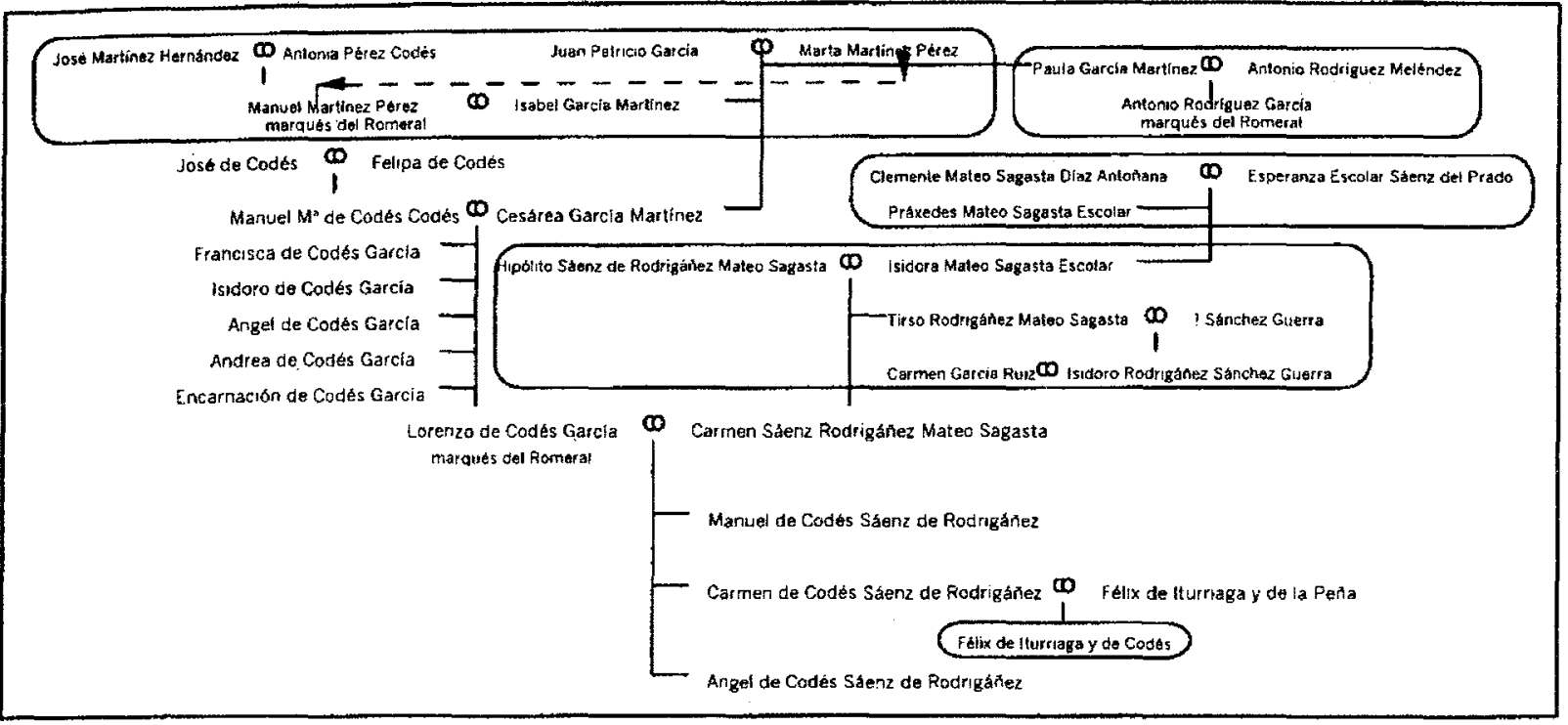

El magistrado y propietario, Ildefonso San Millán Ozolla, casado con Dominga Caballero Momediano, está relacionado con la familia de los Santa Cruz, al ser su mujer hermana de la esposa de José Santa Cruz. Será concejal del Ayuntamiento de Logroño en la década de los ochenta del siglo XIX, ocupando la primera tenencia de alcalde. Declara poseer 144 fanegas, pero a su muerte en octubre de 1894, sin descendencia alguna, todo pasó a manos de su esposa, que murió un año después, revirtiendo todas sus propiedades a los sobrinos de la mujer, Alberto y Crescencia Caballero Valdivielso. Está última con residencia en Valladolid, aparecen contribuyendo con importantes cantidades en los años iniciales del siglo XX. Así en el año de 1900 mientras Crescencia Caballero paga 409,21 pesetas por contribución rústica, su hermano satisface una cuota de 330,31 pesetas. 
Genealogía 11. Familias San Millán-Caballero

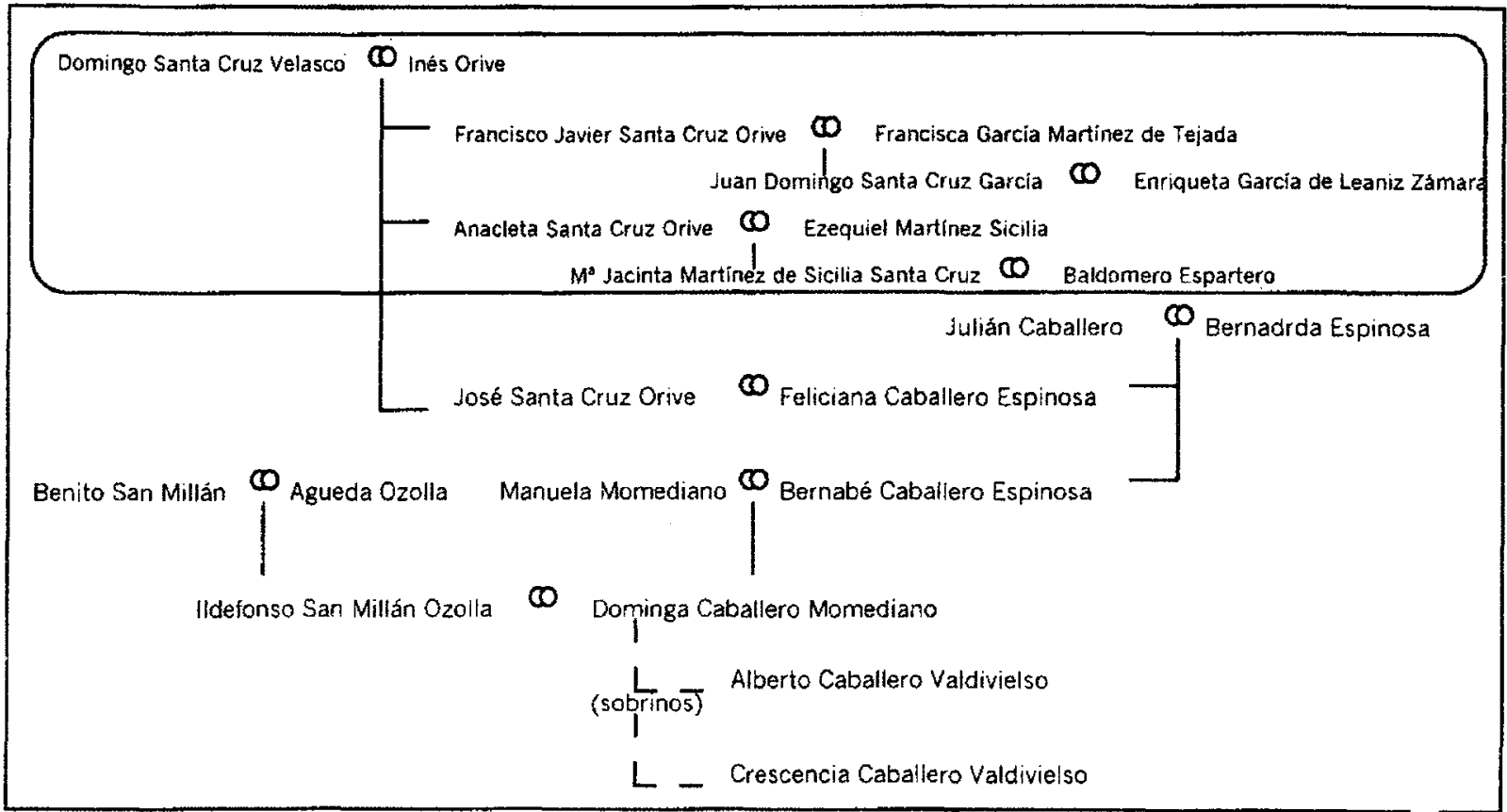

El propietario Saturnino Iñiguez Bretón varias veces diputado provincial a comienzos de la Restauración ${ }^{107}$, era un destacado miembro del partido conservador y de considerable prestigio social en la ciudad de Logroño. Su matrimonio con Carmen Carreras Iragorri, y la unión de las hermanas de ésta con los hermanos Amós y Miguel Salvador Rodrigáñez, emparentó a ambas familias, y los hijos de Saturnino: Isidro ${ }^{108}$ y Francisco Javier ${ }^{109}$ Iñiguez Carreras -véase genealogía 12-, se convirtieron en destacados representantes del partido liberal en la provincia ocupando la alcaldía de Logroño en diversas ocasiones durante la Restauración ${ }^{110}$. Las propiedades que declaró Saturnino Iñiguez Bretón en 1892 llegaban a las 132 fanegas, a su muerte en diciembre de 1890, lega todas sus propiedades a su esposa e hijos Isidro, Francisco Javier y Carmen Iñiguez Carreras ${ }^{111}$, ésta última morirá de meningitis en marzo de 1896 con siete años. Además, Isidro y Javier recibieron los bienes de su tía Victoria Iñiguez

107. Diputado provincial por Canales de la Sierra en 1875, por Torrecilla en 1877 y San Román en 1878. Concejal (Logroño) 1887.

108. Concejal (Logroño) 1897, 1903 (enero), 1903 (noviembre), 1915. $3^{a}$ ten. alc.1899, $2^{\circ}$ proc. sind. 1903. Alcalde Logroño enero 1904-agosto 1906 y enero 1916-julio 1917.

109. Concejal (Logroño) 1909 (mayo), 1913. Alcalde Logroño 1 julio 1909-1 enero 1912. Diputado provincial (Nájera-Torrecilla) 1917.

110. LÓPEZ RODRÍGUEZ, Pedro, Sociedad riojana y..., pp. 140-144.

111. A.N.R.M, (Protocolos Notariales), Notario Plácido Aragón, "Inventario de bienes de Saturnino Iñiguez Bretón", prot. o 74, 27 enero de 1894, ff. 296-400 y "Rectificación al inventario de bienes de Saturnino Iñiguez Bretón" prot. no 417, 19 octubre 1895, ff. 1369-1445 v. 
Bretón, fallecida en septiembre de $1896^{112}$. Durante los primeros años del siglo $\mathrm{XX}$ ambos hermanos aparecen en las listas de mayores contribuyentes de Logroño, así en 1915 mientras Isidro es el segundo máximo contribuyente de Logroño, con una contribución de $1.692,85$ pesetas, su hermano Francisco Javier, aparece en séptimo lugar, pagando $1.517,34$ pesetas $^{113}$. La mayor parte de la contribución es de carácter urbano, no en vano son propietarios de dos de las tres casas palacio, situadas frente al Paseo del Espolón de Logroño, una de las cuales es la actual sede de la Presidencia del Gobierno Autónomo de la Rioja. La tercera casa, donde se ubicará el Gran Hotel perteneció a la familia Herreros de Tejada. El matrimonio de Francisco Javier con Ana Herreros de Tejada, vinculó estas tres fincas urbanas. El arquitecto Francisco de Luis y Tomás, también estaba emparentado con la familia Iñiguez, pues su hija María de Luis Aramayona, se desposó con Isidro Iñiguez Carreras y el mismo, se casó en segundas nupcias con la tía de éste, Victoria Iñiguez Bretón.

Genealogía 12. Familias Iñiguez-Carreras

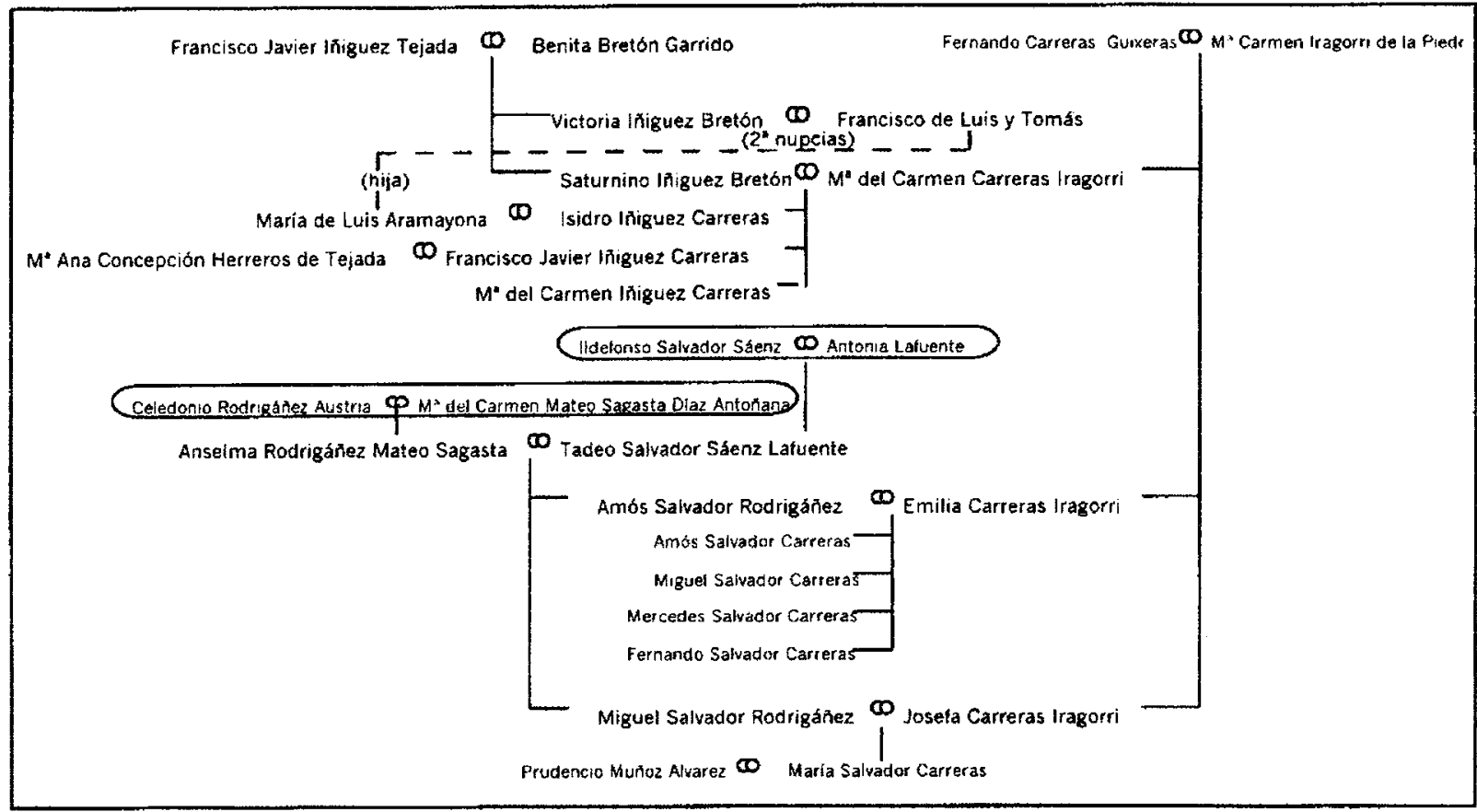

Cipriana Unda y Urien, viuda del rico propietario y abogado logroñés, el diputado provincial Celso Planzón Lebrón Gastetuaga, que satisface una contribución en 1865 de 2.807 pesetas, declara en 1892 una propiedad próxima a las 130 fanegas. En 1891 su hija Joaquina Planzón Unda contrae matrimonio con el abogado y político calceatense Francisco de Paula Marín y Riaño. Este

112. A.N.R.M, (Protocolos Notariales), Notario Plácido Aragón, "Inventario de bienes de Victoria Iñiguez Bretón", prot. no 195, 29 de marzo de 1897, ff. 522-663 v.

113. LOPEZ RODRÍGUEZ, Pedro, Sociedad riojana y..., Cuadro It.15, p. 65 
que aparece en el registro de contribuciones a principios de siglo cotizando 203,54 pesetas por propiedad rústica, llegará a las 207,60 pesetas en 1915, para alcanzar la cifra de 757,25 pesetas en 1925. En cuanto a su actividad política, Francisco de Paula Marín es elegido diputado provincial por el distrito de Haro en 1888. Desde su instalación en Logroño a finales del siglo XIX, ocupa la presidencia de las diversas formaciones republicanas constituidas a finales de la centuria, con motivo de la ansiada unificación partidista. Alcalde de Logroño a principios del siglo XX por el partido republicano, volverá a serlo en 1914, cuando sea elegido concejal, aunque esta vez por el partido conservador ${ }^{134}$. Otro propietario que tiene alguna relación con esta familia es Miguel Zurbano Urien ${ }^{115}$, declara 106 fanegas en el amillaramiento de Logroño y paga en 1900 una cuota de 263,12 pesetas $^{116}$. En el repartimiento de 1910, su contribución queda reducida a la mínima expresión, debido a que las propiedades se han divido como consecuencia del reparto de la herencia entre sus dos hijos, que son los que ahora pasan a ser contribuyentes, aunque pronto vendieron sus propiedades, ya que en 1915, su hija $M^{a}$ Concepción Zurbano Novoa, ya no aparece y su hijo Manuel Zurbano Novoa, paga una cuota insignificante.

El siguiente gran propietario logroñés será el notario Plácido Aragón Ochoa, sin duda una de los personajes más influyentes de la capital logroñesa desde al menos la época del Sexenio Democrático, hasta su muerte el 2 de diciembre de 1902. Conocedor como nadie de los entresijos sociales, económicos y políticos, por su notaría pasarán las más grandes fortunas de la provincia. Su bufete, es, sin duda, el más importante de Logroño durante la Restauración y a él habrá que recurrir para cualquier estudio, que se quiere efectuar sobre este período. Nacido en Anguciana (La Rioja) el 5 de octubre de 1827, localidad próxima a la ciudad de Haro, contrajo matrimonio con la jarrera Dolores Barrón Verde, de la que tuvo dos hijos, Salvador y Saturnino Aragón Barrón -véase genealogía 13-. El primero de ellos casado con Gertrudis Fernández Bazán hija de un gran propietario de Fuenmayor, fue en diversas ocasiones gobernador civil de la provincia de Alava, además de presidente de la Diputación provincial entre 1898 y 1901. Saturnino, por su parte, abogado de profesión, fue concejal del Ayuntamiento de Logroño en 1915, además de ocupar diversos cargos en el comité local de partido liberal y en diversas ocasiones la presidencia del Círculo Logroñés. También relacionado familiarmente con ellos el arquitecto logroñés Luis Barrón Sáenz y el procurador y concejal Román Orive Aragón. Toda la familia estará estrechamente vinculado al partido liberal, en el que ocuparan destacados cargos. Con 120 fanegas según los datos de 1892,

114. LOPEZ RODRÍGUEZ, Pedro, Sociedad riojana y..., Cuadro IV.19, p. 110.

115. Comprador de bienes nacionales en la Desamortización de Espartero, en el año 1843 por valor de 9.900 reales. Véase LÁZARO TORRES, Rosa Mª La desamortización de..., pp. 102-103.

116. Véase Cuadro 9, p. 45. 
paga una contribución rústica de 272,69 pesetas en 1900. En 1915, sus dos hijos tributan conjuntamente una cantidad alrededor de las 400 pesetas por igual concepto, aunque por lo que pagan a Hacienda en ese año se colocan en los puestos décimo y undécimo de la lista de mayores contribuyentes de Logroño, en base a la contribución urbana, cotizando cada uno por encima de las 1.200 pesetas $^{117}$.

Genealogía 13. Familias Aragón-Barrón

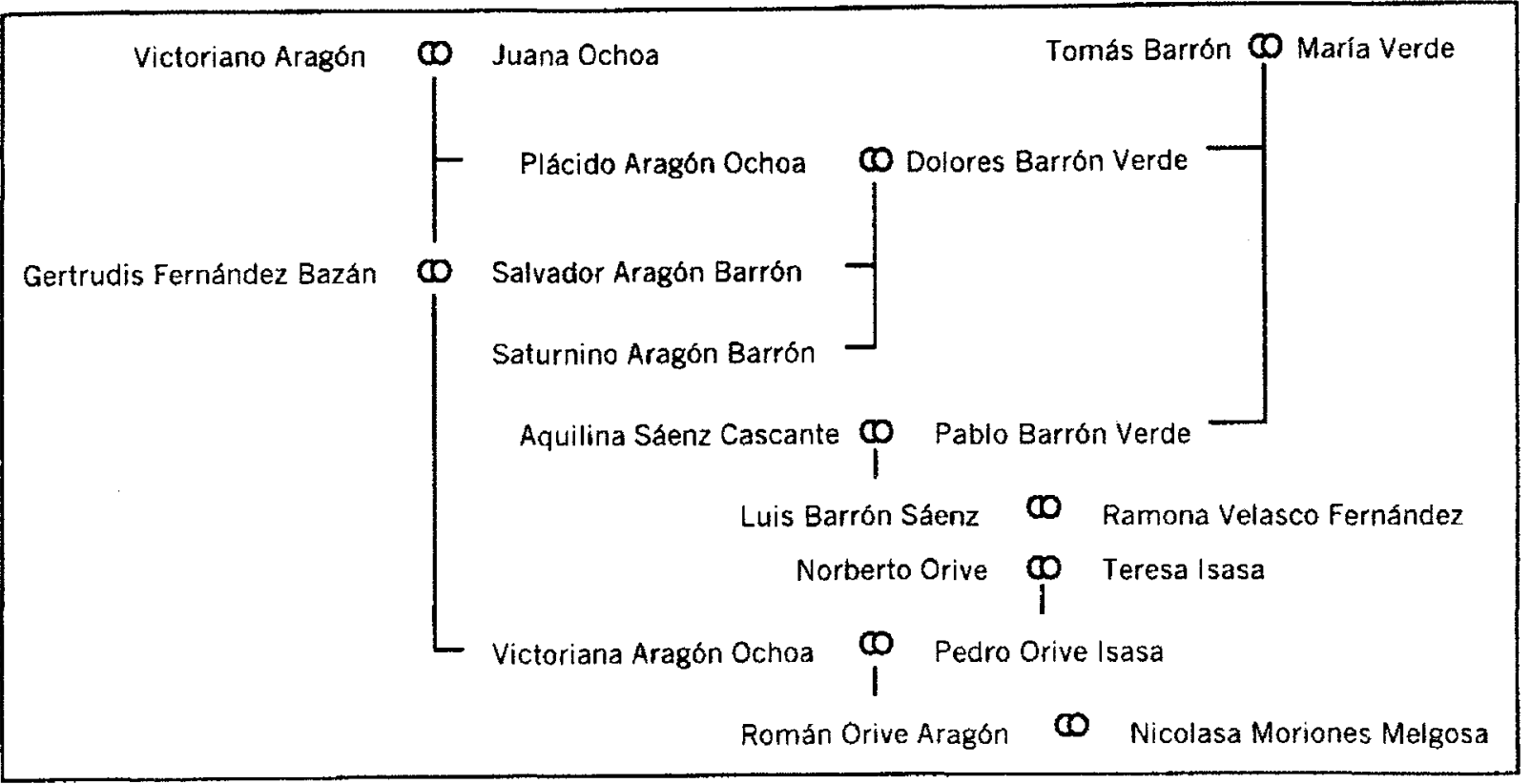

Continuando con los notarios de Logroño, debemos citar a Juan Farias Camargo, originario de la ciudad de Haro y casado con la logroñesa Gregoria Merino Ruiz-Olalde, de cuyo matrimonio tuvieron tres hijos, Joaquín, Julio y Teresa Farias Merino -véase genealogía 14-. Relacionado con ellos el abogado y propietario Juan Manuel Farias Herce. Las propiedades de la familia Farias superan las 200 fanegas según el amillaramiento de 1892, en 1900 Joaquín Farias paga una contribución rústica de 254,83 pesetas y Juan Manuel Farias Herce, tributa por el mismo concepto 378,19 pesetas. El más conocido miembro de esta familia Julio Farias Merino, será elegido concejal de Logroño en las elecciones de 1885 por el partido liberal, siendo secretario del mismo Ayuntamiento desde enero de 1898 a septiembre de 1920. Su matrimonio con Pilar Barona Sáez lo emparentó con el diputado a Cortes, el liberal Miguel Villanueva Gómez. Por su parte, Juan Manuel Farias Herce será concejal en 1889.

117. LÓPEZ RODRíGUEZ, Pedro, Sociedad riojana y..., Cuadro II.15, p. 65. 
Genealogía 14. Familia Farias

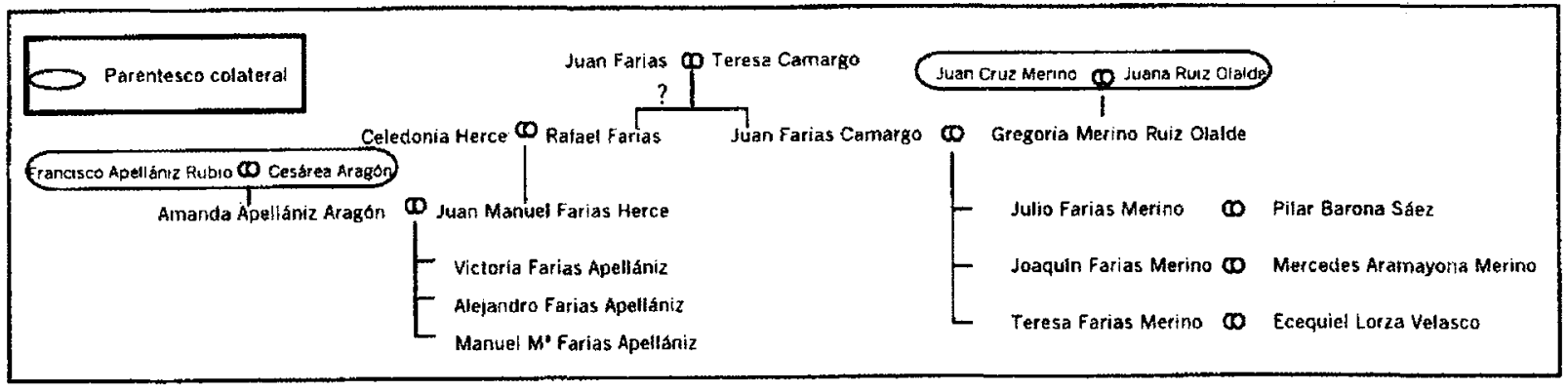

En el barrio de El Cortijo, el apellido Melón identifica a los mayores propietarios de esta barriada logroñesas, que además controlan políticamente. En estos momentos es Mateo Melón Sáenz el más destacado de todos ellos, registrando en 1892 una propiedad de 113 fanegas ${ }^{118}$, por la que satisface en 1900 una contribución rústica de 98,87 pesetas. Será concejal del Ayuntamiento de Logroño en 1887. Su hija Caya Melón Ibarra se unirá con el también concejal logroñés, el labrador Francisco Pérez Caballero. Otros destacados labradores de El Cortijo, también con notable peso social, en un barrio con un alto grado de endogamia son Lucas Sáenz Treviño, que tiene en 1892, 108 fanegas y paga en 1900, 150,98 pesetas de contribución. Eusebio Nalda Torres y Antonio Valdemoros Melón, reúnen una propiedad superior a las 430 fanegas, casi toda ella tierras de escasa calidad y cuya contribución no supera en mucho las cien pesetas a comienzos del siglo XX. En igual caso está Félix Bargo Sierra, que con 163 fanegas paga a en 1900 unos impuestos de 132,57 pesetas y Salvadora Cebada Sáenz, esposa de Lino Bargo Melón, que con 113 fanegas va a pagar en 190049,15 pesetas.

La familia Fernández de Navarrete originarios de la población de Navarrete, pero también con casa solariega en la localidad de Abalos, tiene allí la mayoría de sus posesiones territoriales, destacan en los orígenes de la constitución de la provincia de Logroño ${ }^{119}$. A finales del siglo XIX, sin embargo, volvemos a saber de ellos, por sus relaciones con otro de las grandes propietarios territoriales de la provincia, la familia Mancebo, cuyas principales posesiones

118. Véase Cuadro 9, p. 45.

119. Antonio N. Fernández de Navarrete, vecino de Abalos y uno de los más destacados miembro de la Real Sociedad Económica de la Rioja Castellana es autor de uno de los primeros documentos del "provincialismo" riojano: "Discurso sobre la necesidad, validez y ventajas que resultarían a La Rioja y al Estado, en su erección a Provincia Política de la Monarquía e independiente de las demás" (1813). Martín Fernández de Navarrete es autor de un folleto, escrito bajo un seudónimo, en el que reclama abiertamente la independencia: "Juicio Crítico de la Exposición dirigida al Congreso Nacional por unos apoderados de Soria para que no se altere el estado presente de su provincia y capital. Carta de un Riojano a un Señor Diputado de Cortes" (1821). Ambos escrito se recogen en el libro de ABAD LEÓN, Felipe, La Rioja, provincia... 1982, pp. 113-198 y 258-323. 
se encuentran en la Rioja Baja. Casta Mancebo la mayor propietaria de Calahorra, casa a una de sus hijas Micaela de Rada Mancebo con el ingeniero Antonio Fernández de Navarrete, que tienen su residencia habitual en la ciudad de Zaragoza. Los Fernández de Navarrete reúnen en Logroño, según el amillaramiento de 1892 una propiedad de 111 fanegas. Uno de sus miembros el ingeniero Joaquín Fernández de Navarrete, con residencia en Burgos, satisface en 1900 una contribución en Logroño de 246,71 pesetas. En 1931 su hermano Antonio Fernández de Navarrete, marqués de Legarda aparece como el décimo mayor propietario de La Rioja, con una cuota a la Hacienda Pública de $3.365,81$ pesetas, por las localidades de Alfaro y Abalos. Por su parte, en el amillaramiento de Logroño también aparece Casta Mancebo Agreda ${ }^{120}$, con unas propiedades de 150 fanegas de tierra, en 1900 paga una cuota de 447,58 pesetas, aunque la mayoría de sus posesiones territoriales se encuentran en la Rioja Baja. En 1931, aparece como una de las mayores propietarias de la provincia, situándose en el cuarto lugar en la lista de mayores contribuyentes por territorial de la provincia, con una cuota de $3.971,73$ pesetas. Pero si esta familia destacó por su grandes posesiones territoriales durante todo el siglo XIX y buena parte del $X X$, su relevancia a nivel político, como uno de los principales representantes del partido conservador en nuestra provincia, no fue menor, y los encontramos ya en la constitución de las primeras diputaciones de la Rioja, en la figura de Francisco Mancebo Raón, pero también vemos a diputados a cortes como Pelayo Mancebo Agreda o Francisco Mancebo Igón ${ }^{121}$.

La Condesa de Bornos como en el caso de la Marquesa de la Lapilla forma parte de ese grupo de grandes propietarios territoriales a nivel estatal, la encontramos en la lista de los mayores propietarios con propiedades en varias provincias. Aparece en la lista de 1855, donde el Conde de Bornos es señalado con el número 31 a nivel estatal, con propiedades en 11 provincias españolas, destacando las cuotas contributivas que satisface en Badajoz, Granada, Jaén, Madrid y Toledo, donde alcanza las 23.963 pesetas, Logroño es la octava provincia donde más contribuye con 1.523 pesetas. Sin embargo, no lo encontramos ya en la lista de mayores contribuyentes de 1875 , en ninguna de las provincias citadas ${ }^{122}$. En nuestra ciudad registra en 1892 una cantidad de tierra de 111 fanegas, contribuyendo en 1900 con 459,76 pesetas, que llega a las 817,10 pesetas en 1925. La heredera de todas su propiedades va a ser $M^{a}$ de los Dolores Vélez de Guevara y Pimentel, Condesa de Guevara, a finales de la década de los veinte. La Marquesa de Santa Cruz Aguirre, vecina de Madrid,

120. Sobre la relevancia económica de esta familia véase BERMEJO MARTíN, Francisco y DELGADO IDARRETA, José Miguel, La Diputación provincial..., p. 348. Sobre su importancia política LÓPEZ RODRÍGUEZ, Pedro, Calahorra levítica y liberal..., p. 125-126.

121. Francisco Mancebo Raón será diputado provincial (Calahorra) en 1837, su hijo Pelayo Mancebo Agreda fue diputado a Cortes (Arnedo) 1884 y el hijo de éste Francisco Mancebo Igón lo fue en 1907 (Arnedo).

122. CONGOST, Rosa, "La lista de los mayores...", pp. 306 y ss. 
otra propietaria absentista, aparece con una propiedad de 118 fanegas, su contribución ronda las 180 pesetas en los veinte primeros años de la actual centuria, para situarse en las 231,07 pesetas en 1925.

\section{Genealogía 15. Familia Fernández de Navarrete}

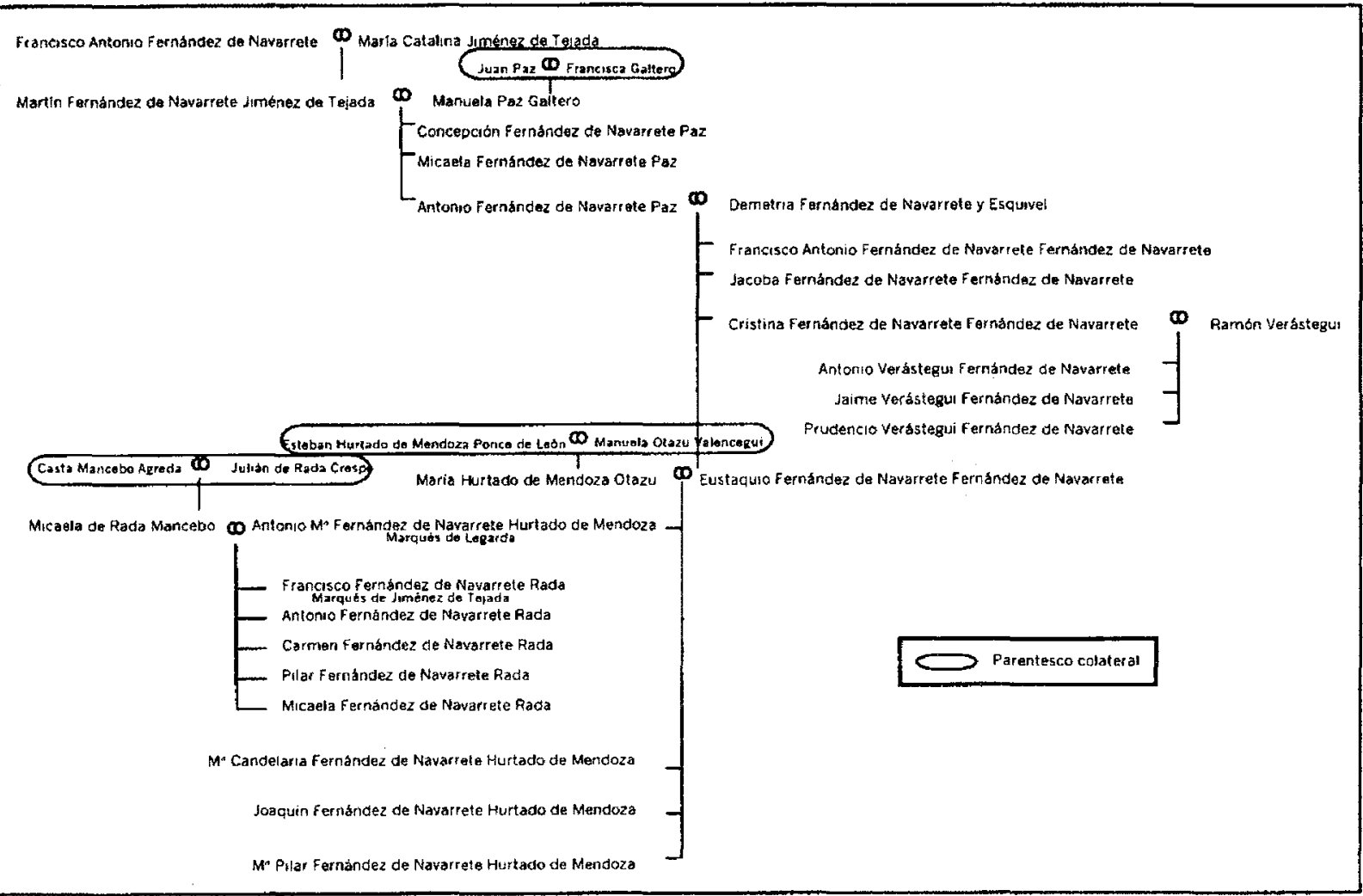

\section{Adenda final: el repliegue de las posiciones políticas de la burguesía logroñesa durante la Restauración}

La caracterización de las clases propietarias de la ciudad de Logroño, permite acercarnos al comportamiento de las élite económica durante la Restauración. A estas alturas del siglo el proceso revolucionario de comienzos del ochocientos se ha consumado, la burguesía ha conseguido una posición social preeminente. El cuestionamiento de la revolución burguesa del siglo $\mathrm{XIX}$, es un debate esteril, pues nadie puede negar que tal proceso tuvo lugar en España en la centuria pasada. El debate planteado en los años de la transición, trató de solventar una controversia social del momento político en que se vivía ${ }^{123}$. Pero en

123. El trabajo que mejor recoge las diversas interpretaciones sobre la revolución burguesa se debe a PÉREZ GARZÓN, Juan Sisinio, "La revolución burguesa en España: los inicios de un debate cientifico, 1966-1979", en TUÑÓN DE LARA, Manuel (ed.), Historiografía española contemporánea, X Coloquio de Pau, Madrid, 1980, pp. 91-138. También es de gran interés 
la actualidad, buscar respuesta a este interrogante, no pasa del puro ejercicio académico de ratificación de un paradigma científico. La investigación histórica debe centrarse en describir los mecanismos de como este proceso se fue consolidando a lo largo del siglo XIX, todavía mal conocidos. El modelo general se encuentra claramente expuesto en el repertorio bibliográfico español, las últimas investigaciones han avanzado extraordinariamente en la constatación de los agentes del cambio ${ }^{124}$, queda pues comprobar en que medida contribuyeron los procesos que se produjeron a lo largo del siglo XIX entre los que la abolición de régimen señorial, desamortización y desvinculación son hasta ahora los temas más recurrentes de la investigación histórica ${ }^{125}$.

La época de la Restauración constituye el punto final de un proceso que se inicia en el siglo XVIII con el arrumbamiento del Antiguo Régimen. A pesar de las reticencias de denominar a tal proceso como revolucionario -con carácter general, revolución expresa un cambio radical en poco tiempo-creo que este "anatema" conceptual es similar al que los historiadores de la antigüedad cometen al hablar de "revolución neolítica", fenómeno de más profundo calado y más larga duración, pero que apenas ha recibido contestación académica, lo que corrobora una vez más el estéril prurito en el que muchas veces se pierde la Academia. Pero obviando estos falsos problemas, el estudio de esta fase final de consolidación de la "propiedad perfecta" constituye un momento ideal para constatar los resultados de la reforma agraria liberal en España.

En el umbral del ochocientos convergen una serie de intereses difícilmente repetibles que hacen de nuestra provincia un modelo privilegiado para estudiar la evolución de la burguesía española, tomando como punto de partida lo concreto de un territorio creado ex novo - La Rioja-, un nuevo marco de relaciones socioeconómicas alumbradas por las corrientes más exaltadas del pensamiento liberal-burgués y un producto -la vid- de alto valor comercial y monetario; la burguesía transformará la antigua prevalencia económica de la ganadería trashumante y la producción pañera camerana -en fase agónica-, convergiendo hacia la tierra como el más seguro valor de uso y el vino como el perfecto producto de intercambio, que multiplicaba el valor añadido de la orientación agrícola del valle del Ebro. La burguesía riojana, consciente de esta realidad económica, apoyó todos los movimientos transformadores de la vieja estructu-

el trabajo de ÁlVAREZ JUNCO, José "A vueltas con la Revolución Burguesa", Zona Abierta, $\mathrm{n}^{\circ}$ 36-37, 1985, pp. 81-106. La última aportación, en este sentido, se debe a GÓMEZ URDÁÑEZ, Gracia, "Reflexiones sobre la revolución burguesa en España. Una aproximación a los orígenes, ideario y práctica del pensamiento liberal", en Brocar, $n^{\circ}$ 20, Logroño, 1996, pp. 327-345.

124. Véase los trabajos recogidos en SAAVEDRA, Pegerto y VILLARES, Ramón (eds), Señores y Campesinos..., Barcelona, 1991.

125. El tema estrella sin duda en la historiografía española es la desamortización, véase en este sentido la extensa bibliografía recogida en RUEDA, Germán, La desamortización de Mendizabal y Espartero en España, Madrid, 1986 y más recientemente editado por este autor, La desamortización en la Península Ibérica, Ayer, nº 9, Madrid, 1993. 
ra socioeconómica antiguoregimental -movimiento afrancesado, trienio liberal, lucha contra el carlismo-. De todos ellos consiguió beneficios concretos de carácter político, social y económico que sirvieron para redondear su privilegiada posición social. Alcanzado este punto, como en el resto de España, la burguesía riojana, hizo recuento de lo que podía perder si mantenía una posición de avanzadilla social y tras los años del Sexenio Democrático, revisó sus principios políticos y consolidó su posición económica. 
Cuadro 7. Evolución de la gran Propiedad en la Ciudad de Logroño de 1751 a 1892

\begin{tabular}{|c|c|c|c|c|c|c|c|c|}
\hline \multicolumn{3}{|c|}{ CATASTRO DEL M. DE LA ENSENADA DE 1751} & \multicolumn{3}{|c|}{ APEO DE GARAY DE 1818} & \multicolumn{3}{|c|}{ AMILLARAMIENTO DE LOGROÑO DE $1892-1893$} \\
\hline Nombre del Propietario & $\begin{array}{l}\text { Condici } \\
\text { on }\end{array}$ & Tot. $F_{n}$. & Nombre del Propietario & $\begin{array}{l}\text { Condici } \\
\text { on }\end{array}$ & Tot. $\mathrm{Fn}$. & Nombre del Propietario & $\begin{array}{l}\text { Condici } \\
\text { ón }\end{array}$ & Tot $\mathrm{Fn}$ \\
\hline Cabildo de ta Redonda & Ecles. & 608 & Domingo Santa Cruz & Seglar & 496 & José Maria Lasuen & Seglar & 2.240 \\
\hline Cabildo de Palacio & Ecles & 605 & Cabildo de Santiago & Ecles. & 490 & José Rodriguez Paterna & Seglar & 1.427 \\
\hline Félix I. Sánchez & Seglar & 517 & Cabildo de la Reconda & Ecles. & 450 & Eusebio Iradier & Seglar & 1.232 \\
\hline Cabildo de Santiago & Ecles. & 374 & Marcial Martinez & Seglar & 436 & Lucas Rodrigáñez & Seglar & 1.033 \\
\hline Colegio de Jesuitas & Ecles & 342 & Marqués de San Nicolás & Seglar & 433 & Juan Domingo Santa Cruz & Seglar & 878 \\
\hline Maria Teresa Galbete & Seglar & 339 & Cesareo A Benito & Seglar & 431 & Lorenzo Codés Garcia, mq. Romeral & Seglar & 819 \\
\hline Francisco Clavijo & Seglar & 330 & Juan Gamarta & Seglar & 406 & Marqués de Murrieta (forastero) & Seglar & 801 \\
\hline Convento Madre de Dios & Ecles. & 309 & Convento Madre de Dios & Ecles. & 381 & Hdos. Marquesa de la Habara & Seglar & 693 \\
\hline Convento de la Merced & Ecles. & 283 & Convento de la Merced & Ecles. & 359 & Melitona Ayarza (Agoncillo) & Seglar & 660 \\
\hline Convento de las Madres Agustinas & Ecles. & 270 & Floriano Alvaro & Seglar & 352 & Bienes del Estado & Seglar & 582 \\
\hline Herederos de Isidro Adana & Seglar & 233,6 & Magdalena del Río & Seglar & 317 & Marqués de San Nicolás & Seglar & 468 \\
\hline Convento de Valbuena & Ecles. & 213 & Convento de Valbuena & Ecles. & 286 & Francisco Aguilera Segura & Seglar & 391 \\
\hline Obra Pia Vélez de Loyola & Ecles. & 204 & Luisa Blázquez & Seglar & 272 & Martin Navasa & Seglar & 370 \\
\hline Gerónimo Ponce de Lèon & Seglar & 203 & Convento de la Trinidad & Ecles. & 272 & Felipe de la Mata Fernández & Seglar & 322 \\
\hline María Antonia Serrano & Seglar & 197,6 & Manuel Careaga & Seglar & 254 & Hdos. Casimiro Miguel y Soret & Seglar & 264 \\
\hline Diego Gamarra & Seglar & 190 & Ambrosio Aranguren & Seglar & 253 & Isabel Orovio Femán dez Urrutia (Alfaro) & Seglar & 257 \\
\hline Convento de la Trinidad & Ecles. & 177 & Convento de San Agustín & Ecles. & 242 & Eusebio Nalda-Antonio Valdemoros & Seglar & 236 \\
\hline Juan Blázquez & Seglar & 173 & Luis Fernández Moreno & Seglar & 235 & Pedro Maria Montoya (Madrid) & Seglar & 214 \\
\hline Pedro E de la Porta & Seglar & 167 & Pedro Briones & Seglar & 227 & Fermin de Castejón Gómez de la Serna & Seglar & 209 \\
\hline & & & Teresa López & Seglar & 223 & Mónica Moreno Vda Martin Alesanco & Seglar & 176 \\
\hline & & & Santo Hospital & Ecles. & 217 & Manuel de Eulate Orovio (Alfaro) & Seglar & 173 \\
\hline & & & Vicente Ydigoras & Seglar & 208 & Paz Almorin & Seg!ar & 168 \\
\hline & & & Julián Planzón & Seglar & 205 & Marquesa de la Lapilla (Madrid) & Seglar & 165 \\
\hline & & & Alejandro Torroba & Seglar & 205 & María del Barrio (Madrid) & Seglar & 165 \\
\hline & & & Cástor de la Calle & Seglar & 196 & Félix Bargo Siena (El Cortijo) & Seglar & 163 \\
\hline & & & Jacinta Martinez de Sicilia & Seglar & 184 & Leocadia Espinosa Urrutia & Seglar & 162 \\
\hline & & & Marqués de Monasterio & Seglar & 183 & & & \\
\hline & & & Marqués de Aravaca & Seglar & 182 & & & \\
\hline & & & Santumina Olavarria & Seglar & 179 & & & \\
\hline & & & Pio Ponce de León & Seglar & 176 & & & \\
\hline & & & Baltasar Vélez & Seglar & 175 & & & \\
\hline & & & Javier V. Contreras & Seglar & 167 & & & \\
\hline & & & Javier Pérez Ortega & Seglar & 167 & & & \\
\hline & & & Tomás Pérez Urabain & Seglar & 164 & & & \\
\hline TOTAL PROPIEDAD, 1751 & & 5.735 & TOTAL PROPIEDAD 1818 & & 9.423 & TOTAL PROPIEDAD, 1892 & & 14.268 \\
\hline
\end{tabular}

Fuentes: ALONSO CASTROVIEJO, Jesús Javier, Problemática agraria y solución burguesa. Logroño, 1750.1833, Logroño, 1991, Cuadro 11, p. 79 y Cuadro 30 , p. 96 y A.H.P.L. (Hacienda), Leg. 4222, Amillaramiento de la Ciudad de Logroño, 1892-1893. Elaboración propia 
Cuadro 8. Distribución de la propiedad de los mayores propietarios de la ciudad de Logroño a finales del siglo XIX (en fn.)

\begin{tabular}{|c|c|c|c|c|c|c|c|c|c|c|c|c|c|c|c|}
\hline Nombre del Propietario & $\begin{array}{l}\text { Sup. } \\
\text { Tot.* }\end{array}$ & $\%$ & $\begin{array}{r}\text { Arbo } \\
\text { leda }\end{array}$ & $\begin{array}{l}\text { Cer. } \\
\text { R. }\end{array}$ & $\begin{array}{c}\text { Cer. } \\
\text { S. }\end{array}$ & $\begin{array}{c}\text { Huert } \\
\mathrm{a}\end{array}$ & $\begin{array}{c}\text { Olv. } \\
\text { R. }\end{array}$ & $\begin{array}{l}\text { Oliv. } \\
\text { S. }\end{array}$ & $\begin{array}{c}\mathrm{V}_{\mathrm{C}}-\mathrm{O} . \\
\mathrm{R}\end{array}$ & $\begin{array}{c}\text { V.-O. } \\
\text { S. }\end{array}$ & $\begin{array}{c}\text { Viña } \\
\text { R. }\end{array}$ & $\begin{array}{l}\text { Viña } \\
\text { S. }\end{array}$ & $\begin{array}{c}\text { Pasto } \\
\text { S }\end{array}$ & Lleco & TOTAL \\
\hline José Maria Lasuen & 2.240 & 15,70 & & & 140 & & & & & 100 & & & 2.000 & & 2.240 \\
\hline José Rodriguez Patema Gilberte & 1.427 & 10,00 & & 147 & 212 & 4 & 26 & 19 & 50 & 11 & 41 & 2 & 796 & 117 & 1.425 \\
\hline Eusebio Iradier Arandia & 1.232 & 8,63 & & 131 & 198 & & 6 & 14 & 5 & & & & 877 & & 1.231 \\
\hline Lucas Rodrigáñez Mateo Sagasta & 1.033 & 7,24 & & 35 & 187 & 4 & & & & & & & 765 & 41 & 1.032 \\
\hline Juan Domingo Santa Cruz García & 878 & 6,15 & & 444 & 196 & 27 & 90 & & 91 & & & 27 & & 2 & 877 \\
\hline Lorenzo Codés Garcia, mq del Romeral & 819 & 5,74 & & 10 & & 4 & & & & & 805 & & & & 819 \\
\hline Luciano Murrieta,mg. de Murrieta (forastero) & 801 & 5,61 & 3 & 15 & 20 & & 45 & & 163 & & 39 & & 515 & & 800 \\
\hline Hdos. Marquesa de la Habana & 693 & 4,86 & & 282 & 80 & 50 & 104 & 4 & 51 & 6 & & & 114 & & 691 \\
\hline Melitona Ayarza (Agoncillo) & 660 & 4.63 & & & & & & & & & & & 660 & & 660 \\
\hline Bienes del Estado & 582 & 4,08 & & 432 & & & 2 & & 32 & & 114 & & & & 580 \\
\hline Diego de Francia, Marqués de San Nicolás & 468 & 3,28 & & 405 & 26 & & & & 28 & & 8 & & & & 467 \\
\hline Francisco Aguilera Segura & 391 & 2,74 & & & 172 & & & & & & & & 210 & 8 & 390 \\
\hline Martín Navasa Ezquerro & 370 & 2,59 & & & & & 3 & & 13 & & & & 354 & & 370 \\
\hline Felipe de la Mata Femández & 322 & 2,26 & & 124 & & 13 & 29 & 4 & 70 & & 81 & & & & 321 \\
\hline Hdos. Casimiro Miguel y Soret & 264 & 1,85 & & 174 & 30 & 5 & 6 & & 38 & & & & & 10 & 263 \\
\hline Isabel Orovio Fernández Urrutia (Alfaro) & 257 & 1,80 & & 219 & & 4 & 10 & & & & & & 23 & & 256 \\
\hline Eusebio Nalda-Antonio Valdemoros & 236 & 1,65 & & & 23 & & & & & & & & 213 & & 236 \\
\hline Pedro María Montoya (Madrid) & 2,4 & 1.50 & & 53 & 44 & 16 & 9 & & 65 & & & & & 26 & 213 \\
\hline Fermin de Castejón Gómez de la Serna & 209 & 1,46 & & 126 & 17 & 29 & & & & & & 17 & & 20 & 209 \\
\hline Mónica Moreno Vda. Martín Alesanco & 176 & 1,23 & & 149 & & & 4 & 16 & & & & 6 & & & 175 \\
\hline Manuel Eulate Orovio (Alfaro) & 173 & $\frac{1,21}{1,21}$ & & 138 & & & 16 & & 19 & & & & & & 173 \\
\hline Paz Almorín Santa Cruz & 168 & 1,18 & & 39 & 14 & 1 & 6 & & 22 & & & & 86 & & 168 \\
\hline Marquesa de la Lapilla (Madrid) & 165 & 1,16 & & 128 & 31 & & 4 & 2 & & & & & & & 165 \\
\hline Maria del Barrio Alvarez (Madrid) & 165 & 1,16 & & 110 & 42 & 11 & 1 & & & & & & & & 164 \\
\hline Félix Bargo Sierra (El Cortijo) & 163 & 1,14 & 2 & 14 & 97 & & 1 & 1 & 12 & 2 & & 14 & 20 & & 163 \\
\hline Leocadia Espinosa Umutia & 162 & 1,14 & & & 25 & & 1 & 3 & 41 & 12 & 7 & 64 & & 6 & 159 \\
\hline & 14.268 & 100,00 & 5 & 3.175 & 1.554 & 168 & 363 & 63 & 700 & 131 & 1.095 & 130 & 6.633 & 230 & 14.247 \\
\hline
\end{tabular}

Fuente: A.H.P.L. (Hacienda), Leg. 4222, Amillaramiento de la Ciudad de Logroño, 1892-1893. Elaboración propia

${ }^{*}$ ) Las diferencias con la suma de los diferentes aprovechamientos se derivan de la transformación de las unidades de medida. 


\begin{tabular}{|c|c|c|c|c|c|c|c|}
\hline Nombre de los Propietarios & Sup. Tot.* & 1900 & 1905 & 1910 & 1915 & 1920 & 1925 \\
\hline José Maria Lasuen (Burdeos) & 2240 & 367,13 & 384,56 & 401,92 & 404,59 & 405,44 & 167,57 \\
\hline José Rodriguez Paterna Gilberte /Vicente Rodriguez Patema Balanzategui \# & 1427 & 786,95 & 722,69 & 771,43 & 794,64 & 811,92 & 1003,85 \\
\hline Eusebio Iradier Arandia / Ecequiel Toledo Fernández Luco & 1232 & 617,93 & 582,8 & 586,99 & 547,17 & 540,32 & 675,4 \\
\hline Lucas Rodrigáñez Mateo Sagasta / Eugenio Amalric Foché & 1033 & 513,33 & 442,34 & 444,23 & 450,41 & 366,36 & 384,05 \\
\hline Juan Domingo Sta. Cruz / Enrique Herreros Tejada Sta. Cruz/Augusto Plasencia & 878 & 2715,41 & 2235,9 & 1557,6 & 1389,65 & 1365,48 & 1519,2 \\
\hline Lorenzo Codés Garcia, marqués del Romeral / Félix de Iturriaga de la Peña & 819 & 508,91 & 441,44 & 411,62 & 424,07 & 448,16 & 551,2 \\
\hline Luciano Murrieta Garcia, marqués de Murrieta & 801 & 1155,85 & 1504,27 & 1542,71 & 1673,24 & 1658,88 & 2073,6 \\
\hline Hdos. Marquesa de la Habana (Madrid) & 693 & 1847,44 & 1572,63 & 1346,79 & 507,89 & 224,4 & 280,6 \\
\hline Melitona Ayarza (Agoncillo) & 660 & & & & & & \\
\hline Bienes del Estado & 582 & 856,8 & 744,5 & 723,69 & 931,96 & 933,92 & 1402,75 \\
\hline Diego de Francia, marqués de San Nicolás / Ricardo de Francia Castejón & 468 & 1534,67 & 1195,25 & 1200,94 & 1198,27 & 1219,2 & 1449,6 \\
\hline Fraricisco Aguilera Segura/José Aguilera Morera & 391 & 341,93 & 369,25 & 463,61 & 427,13 & 333,12 & 360,6 \\
\hline Martín Navasa Ezquerro & 370 & 123,17 & 103,43 & 104,93 & 108,09 & 71,84 & 89,8 \\
\hline Felipe de la Mata Fernández/Dolores, Francisco, Pelayo, Felisa Mata Barrenechea & 322 & 1669,68 & 1525,55 & 1447,52 & 1473,7 & 915,2 & 615,34 \\
\hline Hdos. Casimiro Miguel y Soret & 264 & 508,71 & 376,18 & 376,19 & 387,54 & 388,32 & 485,4 \\
\hline Isabel Orovio Fernandez Umutia (Alfaro) & 257 & 570,84 & 471,67 & 486,85 & 459,83 & 444,6 & 519,2 \\
\hline Eusebio Nalda Torres-Antonio Valdemoros Melón & 236 & 28,52 & 24,04 & 24,02 & 24,74 & 24,8 & \\
\hline Pedro $\mathrm{M}^{\mathrm{a}}$ Montoya (Madrid) / Ricardo Fernández Heredia & 214 & 620,37 & 543,2 & 543,21 & 559,62 & 581,12 & 677,8 \\
\hline Fermin de Castejón Gómez de la Serna & 209 & 857,71 & 664,28 & 664,17 & 684,15 & 673,28 & 807,24 \\
\hline Mónica Moreno Martínez / Victoria y María Sáenz Moreno & 176 & 558,63 & 470,98 & 438,64 & 450,55 & 448,32 & 503,1 \\
\hline Manuel Eulate Orovio (Alfaro) & 173 & 364,61 & 315,4 & 313,87 & 312,46 & 416,5 & 80,81 \\
\hline Paz Almorin Santa Cruz (forastera)/Justo Zugarramurdi Velasco (esposo) & 168 & 184,21 & 110,21 & 110,2 & 113,39 & & \\
\hline Juan y Francisco Diez Monforte / Gumersinda Monturus Diez & 166 & 278,58 & 234,52 & 73,47 & 63,86 & 64,1 & 80 \\
\hline Marquesa de la Lapilla (Madrid) & 165 & 337,92 & 292,23 & 292,3 & 301,12 & 275,84 & 344,8 \\
\hline María del Barrio Alvarez (Madrid) & 165 & 402,61 & 355,26 & 342,71 & 63,55 & 47,04 & 44,4 \\
\hline Félix Bargo Sierra (El Cortijo)/Ana Bargo Valdemoros & 163 & 132,57 & 111,6 & 105,09 & 108,24 & 108,48 & 122,4 \\
\hline Leocadia Espinosa Urrutia / Sebastián Jimeno (esposo) & 162 & 213,58 & 181,5 & 189,28 & 15,04 & 15,04 & \\
\hline Leandro Domínguez Verguilla & 155 & 229,75 & 193,44 & 207,85 & 212,66 & 68,64 & 78,6 \\
\hline José Quintana Rodriguez & 152 & & & & & & \\
\hline Casta Mancebo Agreda (Calahorra) & 150 & 447,58 & 416,94 & 416,95 & 429,5 & 430,4 & 538 \\
\hline Casilda Romero Martínez/ Andrés y Teresa Covarrubias Laguna & 150 & 429,95 & 361,9 & 361,93 & 372,82 & & \\
\hline Ildefonso San Millán/Alberto-Crescencia Caballero (Valladolid) & 144 & 789,53 & 507,2 & 507,16 & 542,06 & 522,72 & 490 \\
\hline Pilar Crespo Vicente (Madrid) & 144 & 202,66 & & & & & \\
\hline Francisco Pedruro Miguel (Laguardia) & 143 & 268,4 & 232,19 & 232,19 & 232,19 & 239,16 & 239,68 \\
\hline José Orive, Ho. de Miguel Orive Argaiz (forastero) & 141 & 550,78 & 480,6 & 11,93 & 12,29 & & \\
\hline Lorenzo Ruiz Garcia/Eusebio y Manuel Ruiz Elías & 140 & 153,19 & 126,79 & & & & \\
\hline José Máía Zubia Martínez (Hormilla) & 138 & 298,33 & 258,07 & 73,01 & 75,04 & 68 & 82 \\
\hline Saturnino Iñiguez Bretón/Familia lñiguez Carreras & 132 & 442,35 & 374,31 & 323,17 & 241,59 & 457,02 & 35,8 \\
\hline
\end{tabular}




\begin{tabular}{|c|c|c|c|c|c|c|c|}
\hline Melchor Fernández Fé & 132 & 359,05 & 302,36 & 327,05 & 336,89 & 337,6 & 422 \\
\hline José $M^{2}$ Fernández Arcellana /Joaquin y Esperanza Fernández Arcellana & 129 & 426,63 & & & & & \\
\hline Asunción Fernández Urrutia Sola/Manuel Ma Femández Heredia (esposo) & 128 & 371,93 & 424,29 & 424,21 & 187,8 & 167,52 & 209,4 \\
\hline Francisco de Paula Marin Riaño / Cipriana Unda Urien (esposa) & 127 & 678,9 & 580,01 & 531,03 & 505,8 & 498,72 & 636 \\
\hline Placido Aragón Ochoa / Salvador y Satumino Aragón Barrón & 120 & 272,69 & 303,34 & 354,02 & 339,12 & 363,84 & 308,4 \\
\hline Narcisa Velasco/Mercedes González del Castillo & 120 & 266,06 & 208,63 & 208,63 & 138,75 & 85,28 & 106,6 \\
\hline Marqués de Santa Cruz Aguirre (Madrid) & 118 & 178,46 & 154,38 & 154,38 & 159,08 & 159,36 & 199,2 \\
\hline Victoriano Alcate Ramírez & 116 & 118,76 & & 2,79 & 2,88 & 108,48 & \\
\hline Salvadora Cebada Sáenz (El Cortijo) / Jacinto González Cebada & 113 & 49,15 & 41,38 & & & & \\
\hline Mateo Melón Sáenz (El Cortijo) / Francisco Pérez Caballero Armentia & 113 & 146,21 & 148,8 & 72,54 & 1,76 & 160,72 & 295,6 \\
\hline Joaquín Fernández de Navarrete (Navarrete) & 111 & 246,71 & 207,9 & 97,8 & 100,75 & 100,96 & 126,2 \\
\hline Condesa Viuda de Bornos (Madrid) / Condesa de Guevara & 111 & 459,76 & 397,82 & 509,02 & 524,33 & 563,52 & 704,4 \\
\hline Lucas Sáenz Trevino (El Cortijo) & 108 & 150,98 & 127,1 & 134,85 & 145,3 & 140,8 & \\
\hline Hdos. de Leoncia Urquiaga y Martina Urquiaga & 107 & & 9,3 & & 4,79 & & \\
\hline Eustasia Martínez & 106 & & & & 5,91 & & \\
\hline Miguel Zurbano Urien $\mathrm{A}^{\mathrm{a}}$ Concepción Zurbano Novoa & 105 & 263,12 & 221,5 & 2,33 & 2,4 & & \\
\hline Eusebio Nalda Torres (El Cortijo) & 105 & 125,57 & 105,71 & 105,71 & 108,89 & 107,84 & \\
\hline Patricio Sáenz San Martín & 102 & 291,22 & 245,05 & & & & \\
\hline Felipe Fernández Umutia Benito del Valle/Fam. Fernández Urrutia Sola & 101 & 775,5 & 676,16 & 594,47 & 481,86 & 308,64 & 315,82 \\
\hline Antonino Castroviejo Solorzano & 99 & 187,62 & 120,75 & 123,85 & 78,56 & 76,8 & 96 \\
\hline
\end{tabular}

Antonino Castroviejo Solorzano

Fuentes: A.H.P.L. (Hacienda), Leg. 4.064, 4.065, 4.066, 4.067, 4.068, Repartimientos de contribución territorial de la ciudad de Logroño

Leg. 4.107 y 4.108, Apendices de Amillaramientos; Leg. 4.222, Amillaramiento de la ciudad de Logroño, 1892-1893. Elaboración propia

(*) Superficie total en fanegas según el Amillaramiento de 1892-1893.

(\#) Cuando aparece más de un nombre separado por una " $f$ " indica generalmente el herdero más directo. 